\title{
Emisje hałasu w górnictwie nafty i gazu - wiertnie
}

\begin{abstract}
W artykule przedstawiono wyniki pomiarów hałasu środowiskowego towarzyszącego pracy urządzeń eksploatowanych na różnych etapach wiercenia otworu. Uzyskane wyniki posłużyły autorom do przeprowadzenia symulacji w celu określenia przybliżonych poziomów mocy akustycznych urządzeń, których równoczesna praca na wiertni była źródłem hałasu na zmierzonym poziomie.
\end{abstract}

Słowa kluczowe: hałas, wiertnia, poziom mocy akustycznej.

\section{Noise emissions in oil and gas mining - drilling}

The article presents the results of environmental noise measurements accompanying the work of equipment operated at different stages of drilling. The obtained results were used by the authors to perform simulations aimed at estimating the approximate sound power levels of devices, for which the simultaneous work on the drilling was the source of noise at the measured level.

Key words: noise, drilling, sound power level.

\section{Wstęp}

Emisje hałasu do środowiska w górnictwie ropy naftowej i gazu ziemnego towarzyszą pracom realizowanym zarówno na etapie poszukiwań, jak i podczas eksploatacji złóż. Hałas emitowany w związku z pracą urządzeń i instalacji może powodować przekraczanie standardów jakości środowiska, a tym samym stwarzać zagrożenie dla środowiska przyrodniczego oraz stanowić uciążliwość dla ludzi, zwłaszcza w przypadku obiektów zlokalizowanych w bliskim sąsiedztwie terenów podlegających ochronie akustycznej [5].

Analizy oddziaływania na klimat akustyczny urządzeń i instalacji stosowanych w górnictwie nafty i gazu są przedmiotem różnego rodzaju ekspertyz, w tym między innymi raportów o oddziaływaniu na środowisko (tzw. raportów OOŚ), opracowywanych z reguły na wstępnym etapie inwestycyjnym, w fazie uzyskiwania przez inwestorów decyzji o środo- wiskowych uwarunkowaniach realizacji planowanego przedsięwzięcia. W praktyce ocenie oddziaływania na środowisko poddawane są przedsięwzięcia znajdujące się na etapie koncepcyjnym, na którym brak jest jeszcze danych technicznych dotyczących urządzeń i instalacji, $w$ tym ich charakterystyk jako źródeł hałasu. W związku z tym opracowujący raporty OOŚ wykorzystują informacje i dane uzyskane z eksploatacji urządzeń pracujących na podobnych obiektach. Przy sporządzaniu ocen oddziaływania pod kątem emisji hałasu niezwykle przydatna jest znajomość poziomów mocy akustycznych źródeł hałasu. Na podstawie tych danych i przy uwzględnieniu warunków środowiskowych charakteryzujących teren planowanych prac można przeprowadzić symulację propagacji hałasu i sporządzić prognozę wpływu pracy analizowanych urządzeń na środowisko akustyczne.

\section{Źródła hałasu na wiertniach}

Źródłem hałasu na wiertniach jest praca wielu urządzeń, w tym przede wszystkim wiertnicy, pomp płuczkowych, wentylatorów, sprężarek powietrza, agregatów oraz podzespołów wchodzących w skład urządzenia wiertniczego i technicznych urządzeń pomocniczych. Część z tych urządzeń pracu- je wewnątrz kontenerów lub posiada własne obudowy dźwiękochłonne (silniki napędowe, pompy płuczkowe, agregaty prądotwórcze), a część działa na zewnątrz (stół wiertniczy, wyciąg, sita wibracyjne, mieszalniki płuczki, wirówki itp.). Wszystkie te urządzenia podczas pracy wiertni emitują hałas, 
którego natężenie jest wypadkową oddziaływań poszczególnych źródeł $[1,4]$.

Prace wiertnicze prowadzone są w systemie ciągłym, całodobowym, w związku z tym urządzenia technologiczne wiertni emitują hałas o ustalonym poziomie dźwięku, w sposób przeważnie równomierny w ciągu doby. Niemniej jednak wielkość emisji hałasu zmienia się w zależności od etapu prac związanych z wierceniem otworu. Każdy z tych etapów, na które składają się operacje: pogłębiania otworu metodą wiercenia, zapuszczania przewodu wiertniczego, wyciągania przewodu wiertniczego, cementowania rur, syfonowa- nia, płukania, cechuje inny poziom hałasu przenikającego do środowiska $[3,4]$.

Poziom hałasu emitowanego z terenu wiertni do środowiska uzależniony jest przede wszystkim od liczby i mocy silników napędzających urządzenia wiertnicze. Stopień uciążliwości hałasowej wiertni, a więc zasięg rozprzestrzeniania się hałasu w środowisku, zależy od parametrów akustycznych urządzeń, ale również od zagospodarowania placu wiertni (usytuowania poszczególnych urządzeń względem siebie, stosowania kontenerów, ekranów dźwiękochłonnych), a także od morfologii terenu otaczającego wiertnię i od sposobu jego użytkowania.

\section{Pomiary i obliczenia hałasu środowiskowego}

Pomiary hałasu będącego wynikiem pracy urządzeń na wiertni wykonano metodą rejestracji elementarnych próbek hałasu zgodnie z metodyką referencyjną opisaną w rozporządzeniu Ministra Środowiska z dnia 30 października 2014 r. w sprawie wymagań w zakresie prowadzenia pomiarów wielkości emisji oraz pomiarów ilości pobieranej wody [6]. Pomiary w trakcie wiercenia otworu przeprowadzono w punktach pomiarowych wyznaczonych na granicy terenu badanego obiektu oraz w jego najbliżej okolicy, w tym na terenach podlegających ochronie (terenach z zabudową mieszkalną). Z uwagi na to, że prace wiertnicze cechuje hałas stały w czasie, to znaczy zmiany poziomu dźwięku nie przekraczają $5 \mathrm{~dB}$, czas pojedynczego pomiaru $t_{0}$ wynosił 60 sekund. W zależności od różnicy między najwyższą a najniższą wartością zmierzonego poziomu hałasu w danym przedziale cza$\mathrm{su}$ - liczba pomiarów ( $n$ ) wynosiła od 3 do 5 . Badania prowadzono w porze dziennej.

Z powodu braku możliwości wykonania pomiarów tła akustycznego przy wyłączonych źródłach hałasu, badania tła wykonano w najbliżej położonych miejscach placu odpowiadających sposobowi użytkowania terenu, w jakim usytuowana była dana wiertnia.

Na podstawie przeprowadzonych pomiarów elementarnych próbek hałasu $\left(L_{A k}\right)$ wyznaczono średni poziom dźwię$\mathrm{ku} L_{A s r}$, a następnie obliczono poziom emisji hałasu w środowisku $\left(L_{A e k}\right)$, stanowiący różnicę średniego poziomu dźwię- $\mathrm{ku} L_{A s r}$ i wartości średniego poziomu tła akustycznego $L_{A t}$ zgodnie ze wzorem:

$$
L_{A e k}=10 \log \left(10^{0,1 L_{A s r}}-10^{0,1} L_{A t}\right)
$$

gdzie:

$L_{A s r}$ - średni poziom dźwięku dla przedziału czasu $\mathrm{t}_{\mathrm{p}}$ lub średni poziom dźwięku dla danego źródła [dB],

$L_{A t}$ - średni poziom tła akustycznego [dB].

Na podstawie wyznaczonych średnich poziomów dźwię$\mathrm{ku} L_{A s r}$ obliczono poziom hałasu $L_{A e q ~}$ W punktach pomiarowych, wyrażony równoważnym poziomem dźwięku A dla czasu odniesienia $\mathrm{T}$, w poszczególnych przedziałach czasu $t_{p}$, przy czym przyjęto, że źródła dźwięku emitują hałas o jednakowym poziomie (ustalonym) w całym czasie odniesienia, czyli $t_{p}=t_{0}$ i w związku z tym $L_{A e k}=L_{A e q}$.

Wyniki pomiarów podano z określeniem niepewności rozszerzonej dla poziomu ufności $p=95 \%$ i współczynnika rozszerzenia $k=2$. Wynik pomiaru poziomu hałasu uzyskany przy zastosowaniu niniejszej metodyki uważa się za prawidłowy, jeśli wartość przedziału niepewności rozszerzonej $\mathrm{U}_{95}$ jest mniejsza lub równa $2,7 \mathrm{~dB}[2,6]$.

Pomiary przeprowadzono, stosując całkujący miernik poziomu dźwięku Bruel \& Kjaer typ 2250 wraz z kalibratorem akustycznym Brüel \& Kjær typ 4231. Użyte urządzenia pomiarowe spełniają wymagania klasy dokładności 1 .

\section{Obiekty badań}

Obiektem badań, na którym wykonano pomiary hałasu emitowanego do środowiska oraz dla którego przeprowadzono obliczenia symulacyjne w programie IMMI w celu określenia przybliżonych wartości mocy akustycznych urządzeń, była wiertnia Parkosz-2K. Pomiary wykonano w porze dziennej. Objęto nimi etapy:
- pogłębiania otworu (wiercenia),

- marszu kontrolnego (podciągania),

- rurowania,

- cementowania.

Odwiert Parkosz-2K wykonywany był za pomocą urządzenia wiertniczego DRILLMEC MR-8000. 


\section{Wyniki pomiarów hałasu emitowanego do środowiska}

W tablicach przedstawiono wartości równoważnego poziomu dźwięku wyznaczone na podstawie przeprowadzonych pomiarów hałasu emitowanego z placu wiertni Parkosz-2K podczas etapów: wiercenia, podciągania (marszu kontrolnego), rurowania i cementowania.

Wyniki pomiarów zaprezentowano na mapach z lokalizacją punktów pomiarowych.

W trakcie wiercenia otworu Parkosz-2K głównymi emitorami hałasu na terenie wiertni były:
- dwa agregaty prądotwórcze Caterpillar Cat C18 o mocy 300 KM każdy,

- silnik Caterpillar Cat C15 o mocy 500 KM, stanowiący napęd wyciągu wiertniczego,

- dwa silniki Caterpillar Cat D398 o mocy 500 KM każdy, stanowiące zasilanie pomp płuczkowych,

- silnik jednostki napędowej Top Drive,

- hamulec.

Zmierzony poziom tła akustycznego wynosił 38,2 dB.

Tablica 1. Wiertnia Parkosz-2K - etap wiercenia

\begin{tabular}{|c|c|c|c|c|c|c|c|}
\hline \multirow{2}{*}{$\begin{array}{l}\text { Oznaczenie } \\
\text { punktu } \\
\text { pomiarowego }\end{array}$} & \multirow{2}{*}{$\begin{array}{c}\text { Wartości równo- } \\
\text { ważnego poziomu } \\
\text { dźwięku A dla czasu } \\
\text { odniesienia } \mathrm{T}\end{array}$} & \multicolumn{2}{|c|}{$\begin{array}{c}\text { Niepewność pomiaru } \mathrm{U}_{95} \\
{[\mathrm{~dB}]}\end{array}$} & \multirow{2}{*}{$\begin{array}{l}\text { Oznaczenie } \\
\text { punktu } \\
\text { pomiarowego }\end{array}$} & \multirow{2}{*}{$\begin{array}{c}\text { Wartości równo- } \\
\text { ważnego poziomu } \\
\text { dźwięku A dla czasu } \\
\text { odniesienia } \mathrm{T}\end{array}$} & \multicolumn{2}{|c|}{$\begin{array}{c}\text { Niepewność pomiaru } \mathrm{U}_{95} \\
{[\mathrm{~dB}]}\end{array}$} \\
\hline & & symbol & wartość & & & symbol & wartość \\
\hline Tło akustyczne & - & $\mathrm{U}_{95}$ & 0,6 & $\mathrm{P} 13$ & 60,5 & $\mathrm{U}_{95}$ & 0,6 \\
\hline $\mathrm{P} 1$ & 63,2 & $\mathrm{U}_{95}$ & 0,6 & P14 & 63,9 & $\mathrm{U}_{95}$ & 0,6 \\
\hline $\mathrm{P} 2$ & 55,3 & $\mathrm{U}_{95}$ & 0,6 & P15 & 60,6 & $\mathrm{U}_{95}$ & 0,6 \\
\hline P3 & 68,6 & $\mathrm{U}_{95}$ & 0,6 & $\mathrm{P} 16$ & 60,3 & $\mathrm{U}_{95}$ & 0,6 \\
\hline $\mathrm{P} 4$ & 65,8 & $\mathrm{U}_{95}$ & 0,7 & $\mathrm{P} 17$ & 66,5 & $\mathrm{U}_{95}$ & 0,6 \\
\hline P5 & 80,8 & $\mathrm{U}_{95}$ & 0,8 & P18 & 59,7 & $\mathrm{U}_{95}$ & 0,6 \\
\hline P6 & 73,4 & $\mathrm{U}_{95}$ & 0,6 & P19 & 55,9 & $\mathrm{U}_{95}$ & 0,7 \\
\hline P7 & 60,5 & $\mathrm{U}_{95}$ & 0,6 & P20 & 52,6 & $\mathrm{U}_{95}$ & 0,7 \\
\hline P8 & 55,4 & $\mathrm{U}_{95}$ & 0,7 & $\mathrm{P} 21$ & 59,9 & $\mathrm{U}_{95}$ & 0,6 \\
\hline P9 & 60,8 & $\mathrm{U}_{95}$ & 0,6 & $\mathrm{P} 22$ & 58,0 & $\mathrm{U}_{95}$ & 0,6 \\
\hline $\mathrm{P} 10$ & 60,3 & $\mathrm{U}_{95}$ & 0,6 & $\mathrm{P} 23$ & 53,5 & $\mathrm{U}_{95}$ & 0,7 \\
\hline P11 & 62,0 & $\mathrm{U}_{95}$ & 0,6 & $\mathrm{P} 24$ & 48,7 & $\mathrm{U}_{95}$ & 0,6 \\
\hline $\mathrm{P} 12$ & 60,7 & $\mathrm{U}_{95}$ & 0,8 & $\mathrm{P} 25$ & 43,7 & $\mathrm{U}_{95}$ & 0,6 \\
\hline
\end{tabular}



Rys. 1. Lokalizacja punktów pomiarowych wokół wiertni Parkosz-2K wraz ze zmierzonym poziomem dźwięku - etap wiercenia 
W trakcie marszu kontrolnego (podciągania) głównymi emitorami hałasu na terenie wiertni Parkosz-2K były:

- dwa agregaty prądotwórcze Caterpillar Cat C18 o mocy 300 KM każdy,

- silnik Caterpillar Cat C15 o mocy 500 KM, stanowiący napęd wyciągu wiertniczego,
- silnik Caterpillar Cat D398 o mocy 500 KM, stanowiący zasilanie pompy płuczkowej,

- taśmy hamulcowe wyciągu.

Zmierzony poziom tła akustycznego wynosił 33,5 dB.

$\mathrm{W}$ trakcie rurowania głównymi emitorami hałasu na terenie wiertni Parkosz-2K były:

Tablica 2. Wiertnia Parkosz-2K - etap marszu kontrolnego

\begin{tabular}{|c|c|c|c|c|c|c|c|}
\hline \multirow{2}{*}{$\begin{array}{l}\text { Oznaczenie } \\
\text { punktu } \\
\text { pomiarowego }\end{array}$} & \multirow{2}{*}{$\begin{array}{c}\text { Wartości równo- } \\
\text { ważnego poziomu } \\
\text { dźwięku A dla czasu } \\
\text { odniesienia T } \\
\text { L }_{\text {Aeq }}[\mathrm{dB}]\end{array}$} & \multicolumn{2}{|c|}{$\begin{array}{l}\text { Niepewność pomiaru } \mathrm{U}_{95} \\
{[\mathrm{~dB}]}\end{array}$} & \multirow{2}{*}{$\begin{array}{l}\text { Oznaczenie } \\
\text { punktu } \\
\text { pomiarowego }\end{array}$} & \multirow{2}{*}{$\begin{array}{c}\text { Wartości równo- } \\
\text { ważnego poziomu } \\
\text { dźwięku A dla czasu } \\
\text { odniesienia } \mathrm{T}\end{array}$} & \multicolumn{2}{|c|}{$\begin{array}{c}\text { Niepewność pomiaru } \mathrm{U}_{95} \\
{[\mathrm{~dB}]}\end{array}$} \\
\hline & & symbol & wartość & & & symbol & wartość \\
\hline Tło akustyczne & - & $\mathrm{U}_{95}$ & 0,6 & P16 & 61,2 & $\mathrm{U}_{95}$ & 0,6 \\
\hline $\mathrm{P} 1$ & 61,9 & $\mathrm{U}_{95}$ & 0,8 & $\mathrm{P} 17$ & 60,2 & $\mathrm{U}_{95}$ & 0,7 \\
\hline $\mathrm{P} 2$ & 49,6 & $\mathrm{U}_{95}$ & 0,6 & P18 & 60,6 & $\mathrm{U}_{95}$ & 0,8 \\
\hline P3 & 63,5 & $\mathrm{U}_{95}$ & 0,7 & P19 & 59,5 & $\mathrm{U}_{95}$ & 0,6 \\
\hline $\mathrm{P} 4$ & 60,1 & $\mathrm{U}_{95}$ & 0,6 & $\mathrm{P} 20$ & 59,3 & $\mathrm{U}_{95}$ & 0,6 \\
\hline P5 & 80,0 & $\mathrm{U}_{95}$ & 0,6 & $\mathrm{P} 21$ & 55,6 & $\mathrm{U}_{95}$ & 0,7 \\
\hline P6 & 72,3 & $\mathrm{U}_{95}$ & 0,6 & $\mathrm{P} 22$ & 60,4 & $\mathrm{U}_{95}$ & 0,6 \\
\hline P7 & 62,3 & $\mathrm{U}_{95}$ & 0,6 & $\mathrm{P} 23$ & 53,4 & $\mathrm{U}_{95}$ & 0,6 \\
\hline P8 & 55,8 & $\mathrm{U}_{95}$ & 0,6 & $\mathrm{P} 24$ & 53,6 & $\mathrm{U}_{95}$ & 0,6 \\
\hline P9 & 49,5 & $\mathrm{U}_{95}$ & 0,6 & $\mathrm{P} 25$ & 46,0 & $\mathrm{U}_{95}$ & 0,6 \\
\hline P10 & 50,0 & $\mathrm{U}_{95}$ & 0,6 & $\mathrm{P} 26$ & 39,5 & $\mathrm{U}_{95}$ & 0,6 \\
\hline P11 & 54,6 & $\mathrm{U}_{95}$ & 0,7 & $\mathrm{P} 27$ & 38,3 & $\mathrm{U}_{95}$ & 0,6 \\
\hline $\mathrm{P} 12$ & 60,5 & $\mathrm{U}_{95}$ & 0,6 & P28 & 33,1 & $\mathrm{U}_{95}$ & 0,6 \\
\hline P13 & 62,5 & $\mathrm{U}_{95}$ & 0,6 & P29 & 40,7 & $\mathrm{U}_{95}$ & 0,6 \\
\hline P14 & 60,7 & $\mathrm{U}_{95}$ & 0,6 & $\mathrm{P} 30$ & 50,4 & $\mathrm{U}_{95}$ & 0,6 \\
\hline P15 & 57,7 & $\mathrm{U}_{95}$ & 0,6 & P31 & 52,2 & $\mathrm{U}_{95}$ & 0,6 \\
\hline
\end{tabular}

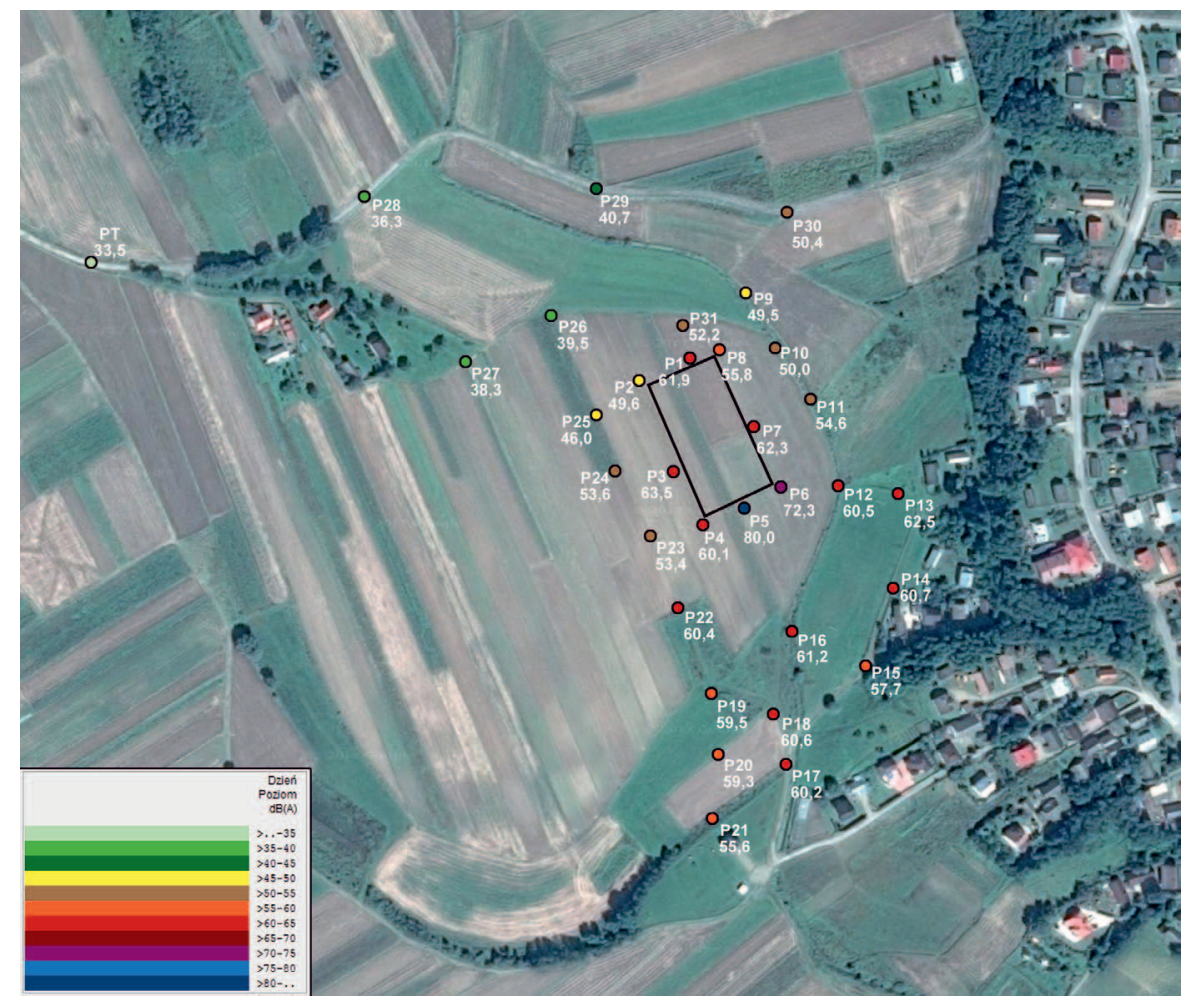

Rys. 2. Lokalizacja punktów pomiarowych wokół wiertni Parkosz-2K wraz ze zmierzonym poziomem dźwięku - etap marszu kontrolnego 
- silnik Caterpillar Cat C15 o mocy 500 KM, stanowiący napęd wyciągu wiertniczego,

- silnik jednostki napędowej Top Drive,

- agregat prądotwórczy Caterpillar Cat C18 o mocy 300 KM,

- taśmy hamulcowe wyciągu,

- silnik napędowy klucza hydraulicznego,

- samojezdny dźwig do podawania rur.

Zmierzony poziom tła akustycznego wynosił $34,7 \mathrm{~dB}$.
W trakcie cementowania odwiertu głównymi emitorami hałasu na terenie wiertni Parkosz-2K były:

- samojezdny agregat cementacyjny,

- samojezdny mikser,

- agregat prądotwórczy Caterpillar Cat C18 o mocy 300 KM,

- silnik Caterpillar Cat D398 o mocy 500 KM, stanowiący zasilanie pompy płuczkowej.

Zmierzony poziom tła akustycznego wynosił $34,7 \mathrm{~dB}$.

Tablica 3. Wiertnia Parkosz-2K - etap rurowania

\begin{tabular}{|c|c|c|c|c|c|c|c|}
\hline \multirow{2}{*}{$\begin{array}{l}\text { Oznaczenie } \\
\text { punktu pomia- } \\
\text { rowego }\end{array}$} & \multirow{2}{*}{$\begin{array}{c}\text { Wartości równo- } \\
\text { ważnego poziomu } \\
\text { dźwięku A dla czasu } \\
\text { odniesienia } \mathrm{T} \\
\mathrm{L}_{\mathrm{Aeq}}[\mathrm{dB}]\end{array}$} & \multicolumn{2}{|c|}{$\begin{array}{c}\text { Niepewność pomiaru } \mathrm{U}_{95} \\
{[\mathrm{~dB}]}\end{array}$} & \multirow{2}{*}{$\begin{array}{l}\text { Oznaczenie } \\
\text { punktu pomia- } \\
\text { rowego }\end{array}$} & \multirow{2}{*}{$\begin{array}{c}\text { Wartości równo- } \\
\text { ważnego poziomu } \\
\text { dźwięku A dla czasu } \\
\text { odniesienia T }\end{array}$} & \multicolumn{2}{|c|}{$\begin{array}{c}\text { Niepewność pomiaru } \mathrm{U}_{95} \\
{[\mathrm{~dB}]}\end{array}$} \\
\hline & & symbol & wartość & & & symbol & wartość \\
\hline Tło akustyczne & - & $\mathrm{U}_{95}$ & 0,7 & $\mathrm{P} 12$ & 58,7 & $\mathrm{U}_{95}$ & 0,6 \\
\hline $\mathrm{P} 1$ & 59,2 & $\mathrm{U}_{95}$ & 0,7 & P13 & 58,3 & $\mathrm{U}_{95}$ & 0,6 \\
\hline $\mathrm{P} 2$ & 54,0 & $\mathrm{U}_{95}$ & 0,6 & $\mathrm{P} 14$ & 56,6 & $\mathrm{U}_{95}$ & 0,8 \\
\hline P3 & 64,3 & $\mathrm{U}_{95}$ & 0,6 & P15 & 59,3 & $\mathrm{U}_{95}$ & 0,7 \\
\hline P4 & 67,7 & $\mathrm{U}_{95}$ & 0,6 & P16 & 56,9 & $\mathrm{U}_{95}$ & 0,7 \\
\hline P5 & 74,6 & $\mathrm{U}_{95}$ & 0,7 & $\mathrm{P} 17$ & 54,2 & $\mathrm{U}_{95}$ & 0,7 \\
\hline P6 & 69,8 & $\mathrm{U}_{95}$ & 0,6 & P18 & 51,1 & $\mathrm{U}_{95}$ & 0,7 \\
\hline P7 & 67,9 & $\mathrm{U}_{95}$ & 0,6 & P19 & 45,1 & $\mathrm{U}_{95}$ & 0,6 \\
\hline P8 & 61,2 & $\mathrm{U}_{95}$ & 0,6 & $\mathrm{P} 20$ & 43,9 & $\mathrm{U}_{95}$ & 0,6 \\
\hline P9 & 52,8 & $\mathrm{U}_{95}$ & 0,7 & $\mathrm{P} 21$ & 39,8 & $\mathrm{U}_{95}$ & 0,6 \\
\hline $\mathrm{P} 10$ & 57,9 & $\mathrm{U}_{95}$ & 0,6 & $\mathrm{P} 22$ & 45,6 & $\mathrm{U}_{95}$ & 0,6 \\
\hline P11 & 55,3 & $\mathrm{U}_{95}$ & 0,6 & $\mathrm{P} 23$ & 53,3 & $\mathrm{U}_{95}$ & 0,6 \\
\hline
\end{tabular}

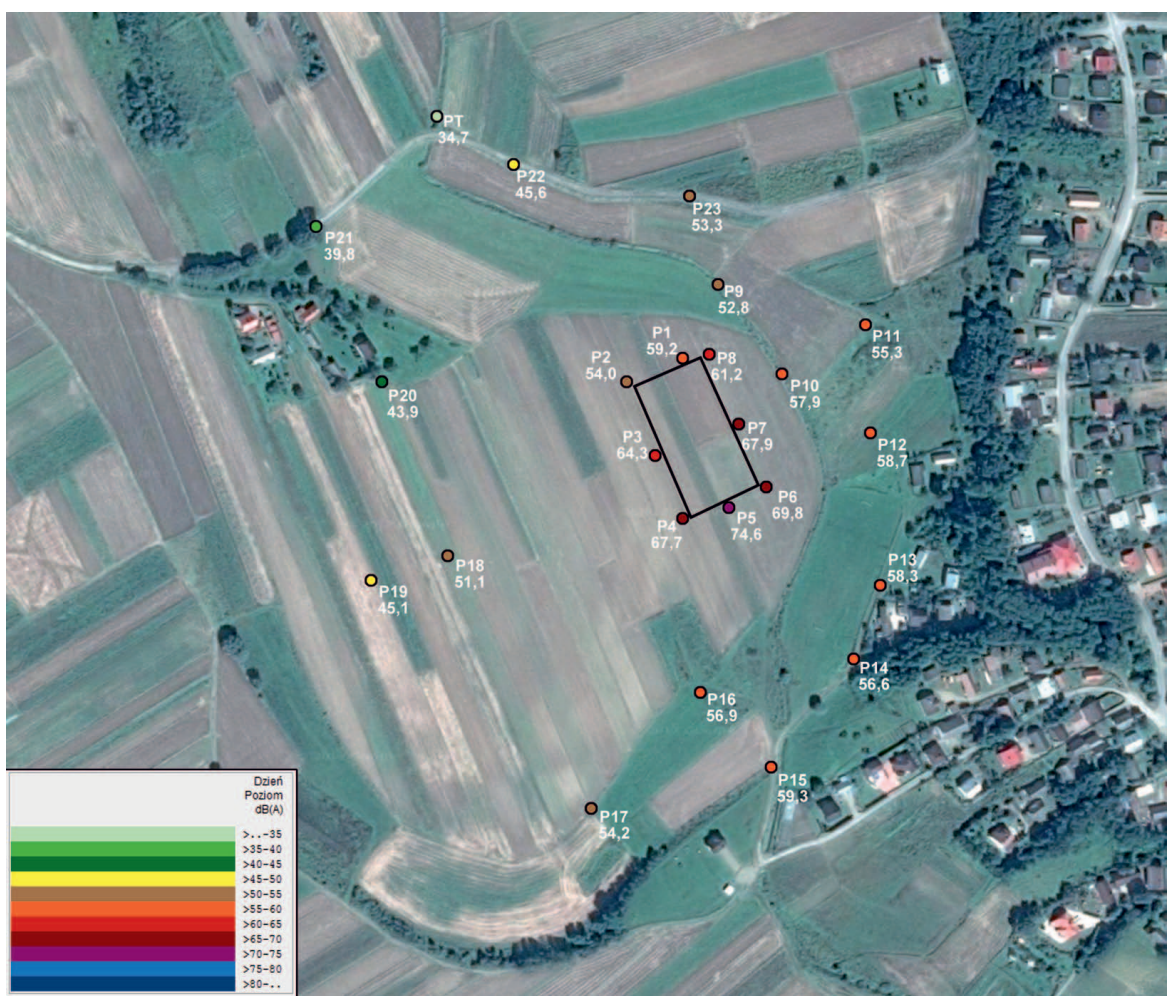

Rys. 3. Lokalizacja punktów pomiarowych wokół wiertni Parkosz-2K wraz ze zmierzonym poziomem dźwięku - etap rurowania 
Tablica 4. Wiertnia Parkosz-2K - etap cementowania

\begin{tabular}{|c|c|c|c|c|c|c|c|}
\hline \multirow{2}{*}{$\begin{array}{l}\text { Oznaczenie } \\
\text { punktu pomia- } \\
\text { rowego }\end{array}$} & \multirow{2}{*}{$\begin{array}{c}\text { Wartości równo- } \\
\text { ważnego poziomu } \\
\text { dźwięku A dla czasu } \\
\text { odniesienia T } \\
\text { L }_{\text {Aeq }}[\mathrm{dB}]\end{array}$} & \multicolumn{2}{|c|}{$\begin{array}{c}\text { Niepewność pomiaru } \mathrm{U}_{95} \\
{[\mathrm{~dB}]}\end{array}$} & \multirow{2}{*}{$\begin{array}{l}\text { Oznaczenie } \\
\text { punktu pomia- } \\
\text { rowego }\end{array}$} & \multirow{2}{*}{$\begin{array}{c}\text { Wartości równo- } \\
\text { ważnego poziomu } \\
\text { dźwięku A dla czasu } \\
\text { odniesienia } \mathrm{T} \\
\mathrm{L}_{\text {Aeq }}[\mathrm{dB}]\end{array}$} & \multicolumn{2}{|c|}{$\begin{array}{c}\text { Niepewność pomiaru } \mathrm{U}_{95} \\
{[\mathrm{~dB}]}\end{array}$} \\
\hline & & symbol & wartość & & & symbol & wartość \\
\hline Tło akustyczne & - & $\mathrm{U}_{95}$ & 0,7 & P11 & 52,0 & $\mathrm{U}_{95}$ & 0,6 \\
\hline $\mathrm{P} 1$ & 67,6 & $\mathrm{U}_{95}$ & 0,6 & P12 & 55,4 & $\mathrm{U}_{95}$ & 0,6 \\
\hline $\mathrm{P} 2$ & 55,0 & $\mathrm{U}_{95}$ & 0,6 & $\mathrm{P} 13$ & 54,8 & $\mathrm{U}_{95}$ & 0,6 \\
\hline P3 & 70,8 & $\mathrm{U}_{95}$ & 0,6 & P14 & 52,0 & $\mathrm{U}_{95}$ & 0,6 \\
\hline $\mathrm{P} 4$ & 59,6 & $\mathrm{U}_{95}$ & 0,6 & $\mathrm{P} 15$ & 46,4 & $\mathrm{U}_{95}$ & 0,6 \\
\hline $\mathrm{P} 5$ & 80,2 & $\mathrm{U}_{95}$ & 0,6 & P16 & 37,7 & $\mathrm{U}_{95}$ & 0,7 \\
\hline P6 & 69,0 & $\mathrm{U}_{95}$ & 0,8 & $\mathrm{P} 17$ & 46,4 & $\mathrm{U}_{95}$ & 0,6 \\
\hline $\mathrm{P} 7$ & 73,5 & $\mathrm{U}_{95}$ & 0,6 & $\mathrm{P} 18$ & 48,4 & $\mathrm{U}_{95}$ & 0,7 \\
\hline P8 & 65,2 & $\mathrm{U}_{95}$ & 0,7 & P19 & 54,9 & $\mathrm{U}_{95}$ & 0,6 \\
\hline P9 & 59,4 & $\mathrm{U}_{95}$ & 0,8 & $\mathrm{P} 20$ & 38,6 & $\mathrm{U}_{95}$ & 0,6 \\
\hline $\mathrm{P} 10$ & 52,3 & $\mathrm{U}_{95}$ & 0,6 & & & & \\
\hline
\end{tabular}

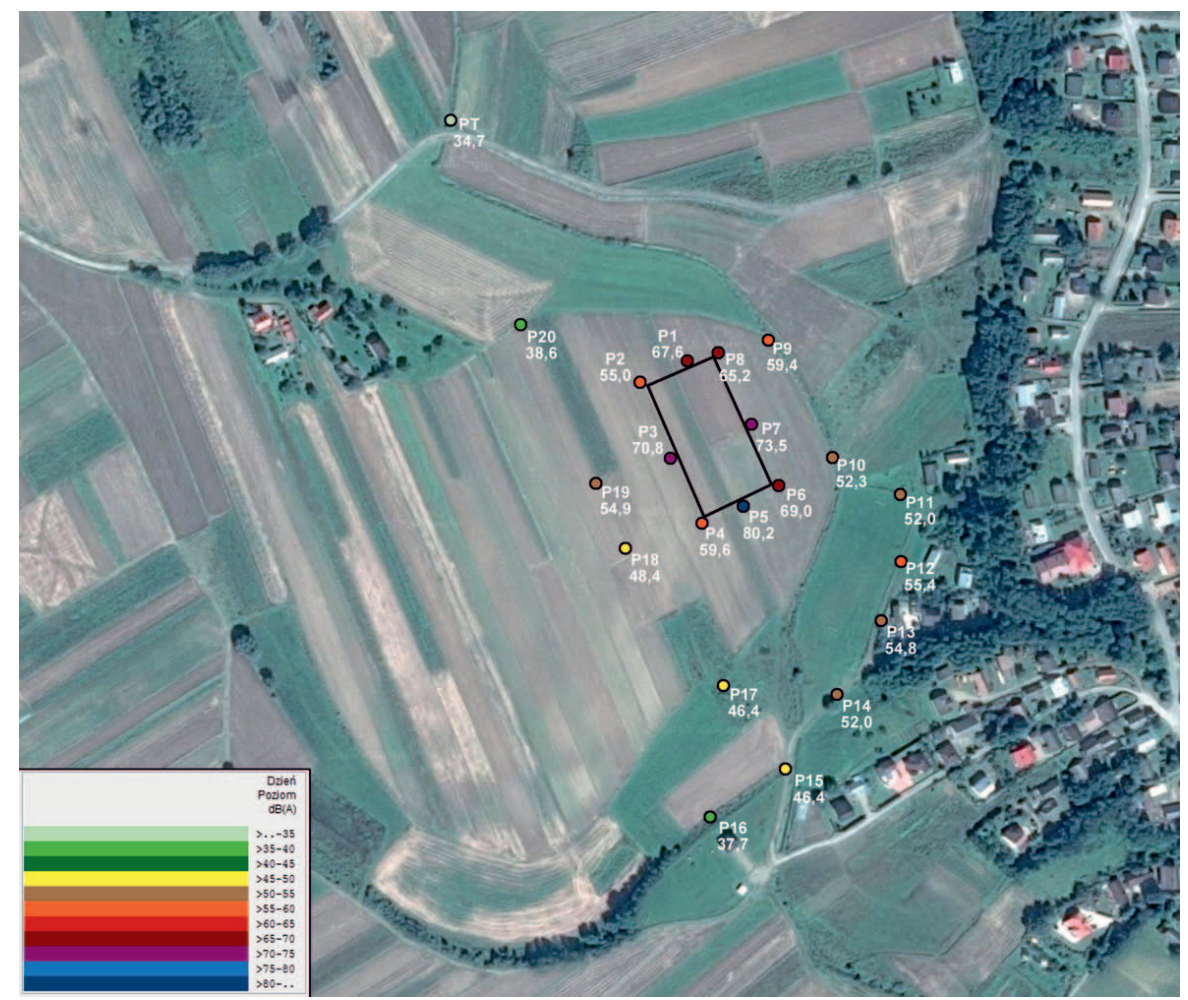

Rys. 4. Lokalizacja punktów pomiarowych wokół wiertni Parkosz-2K wraz ze zmierzonym poziomem dźwięku - etap cementowania

\section{Symulacje komputerowe rozprzestrzeniania się hałasu w środowisku}

Wykorzystując wyniki z pomiarów oraz program IMMI do prognozowania i obliczeń rozprzestrzeniania się hałasu w środowisku, przeprowadzono symulacje pozwalające określić przybliżone poziomy mocy akustycznych urządzeń, których równoczesna praca na wiertni na poszczególnych etapach wiercenia otworu (z obciążeniem właściwym dla danego etapu) była źródłem hałasu na zmierzonym poziomie. Innymi słowy, symulacja miała na celu taki dobór wartości poziomów mocy akustycznych, dla których sumaryczny poziom emisji z pracy wszystkich źródeł hałasu w punktach kontrolnych był jak najbliższy pomierzonym wartościom hałasu środowiskowego.

Ze względu na specyfikę instalacji i sposób ich eksploatacji (jednoczesna praca wielu urządzeń znajdujących się w bliskiej odległości, znacznie oddziałujących na siebie) na obiekcie, jakim jest wiertnia, nie ma możliwości wyznaczenia poziomów mocy akustycznej poszczególnych źródeł hałasu na podstawie pomiarów ciśnienia akustycznego. 
W kolejnych tabelach przedstawiono przybliżone wartości poziomów mocy akustycznej uzyskane w drodze symulacji wykonanej przy użyciu programu IMMI dla poszczegól- nych etapów prac realizowanych na wiertni Parkosz-2K. Na rysunkach zaprezentowano wyniki symulacji rozprzestrzeniania się hałasu z placu wiertni na analizowanych etapach prac.
Tablica 5. Wartości poziomów mocy akustycznej poszczególnych emitorów otrzymane z symulacji; odwiert Parkosz-2K - etap wiercenia

\begin{tabular}{|l|c|}
\hline \multicolumn{1}{|c|}{ Urządzenie } & $\begin{array}{c}\text { Określony w symulacji } \\
\text { poziom mocy akustycznej } \\
L_{W A}[\mathrm{~dB}]\end{array}$ \\
\hline $\begin{array}{l}\text { Agregat prądotwórczy } \\
\text { Caterpillar Cat C18 o mocy } \\
300 \text { KM }\end{array}$ & 119,1 \\
\hline $\begin{array}{l}\text { Agregat prądotwórczy } \\
\text { Caterpillar Cat C18 o mocy } \\
300 \text { KM }\end{array}$ & 118,3 \\
\hline $\begin{array}{l}\text { Silnik Caterpillar Cat C15 } \\
\text { o mocy 500 KM, stanowiący } \\
\text { napęd wyciągu wiertniczego }\end{array}$ & 120,4 \\
\hline $\begin{array}{l}\text { Silnik Caterpillar Cat D398 } \\
\text { o mocy 500 KM, stanowiący } \\
\text { zasilanie pompy płuczkowej }\end{array}$ & 113,8 \\
\hline $\begin{array}{l}\text { Silnik Caterpillar Cat D398 } \\
\text { o mocy 500 KM, stanowiący } \\
\text { zasilanie pompy płuczkowej }\end{array}$ & 114,2 \\
\hline $\begin{array}{l}\text { Silnik jednostki napędowej } \\
\text { Top Drive }\end{array}$ & 103,0 \\
\hline Taśmy hamulcowe wyciągu & 92,1 \\
\hline
\end{tabular}

Tablica 6. Wartości poziomów mocy akustycznej poszczególnych emitorów otrzymane z symulacji; odwiert Parkosz-2K - marsz kontrolny

\begin{tabular}{|l|c|}
\hline \multicolumn{1}{|c|}{ Urządzenie } & $\begin{array}{c}\text { Określony w symulacji } \\
\text { poziom mocy akustycznej } \\
L_{W A}[\mathrm{~dB}]\end{array}$ \\
\hline $\begin{array}{l}\text { Agregat prądotwórczy } \\
\text { Caterpillar Cat C18 o mocy } \\
300 \mathrm{KM}\end{array}$ & 118,2 \\
\hline $\begin{array}{l}\text { Agregat prądotwórczy } \\
\text { Caterpillar Cat C18 o mocy } \\
300 \text { KM }\end{array}$ & 118,3 \\
\hline $\begin{array}{l}\text { Silnik Caterpillar Cat C15 } \\
\text { o mocy 500 KM, stanowiący } \\
\text { napęd wyciągu wiertniczego }\end{array}$ & 118,5 \\
\hline $\begin{array}{l}\text { Silnik Caterpillar Cat D398 } \\
\text { o mocy 500 KM, stanowiący } \\
\text { zasilanie pompy płuczkowej }\end{array}$ & 110,7 \\
\hline Taśmy hamulcowe wyciągu & 103,6 \\
\hline
\end{tabular}

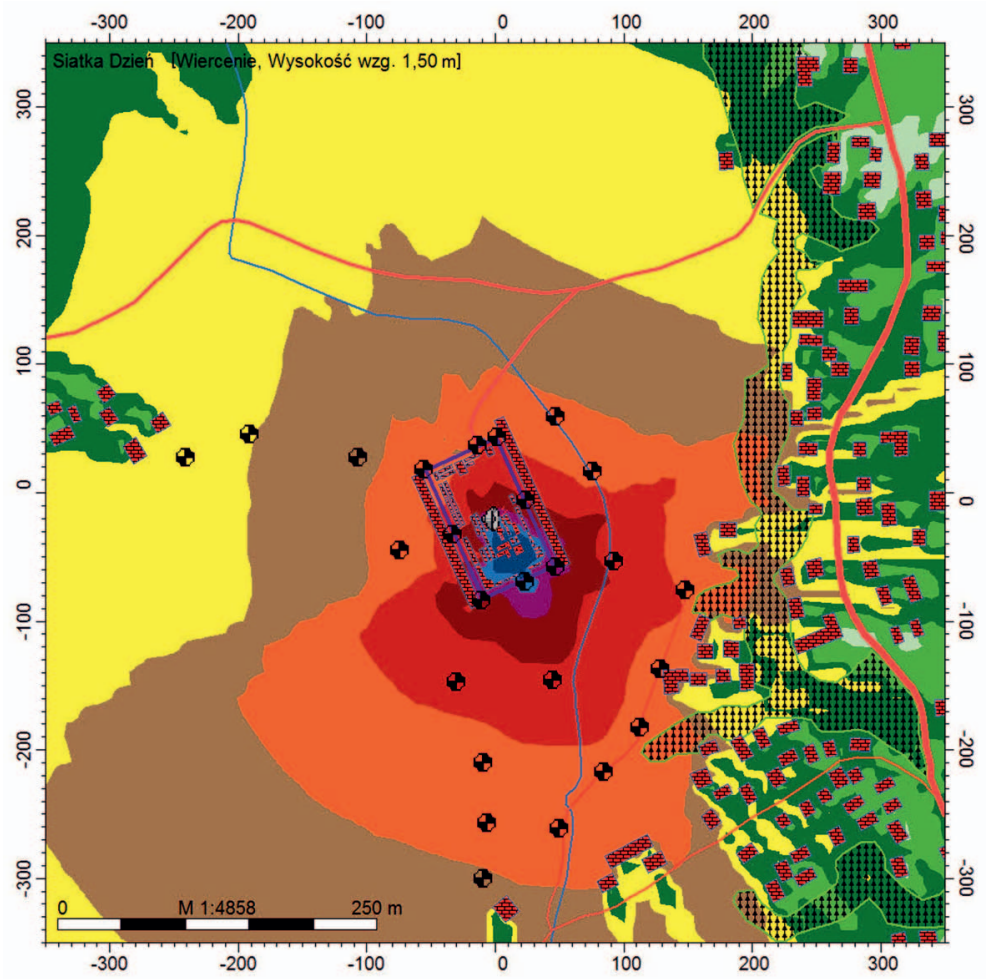

Rys. 5. Symulacja rozprzestrzeniania się hałasu wokół wiertni, odwiert Parkosz-2K - etap wiercenia

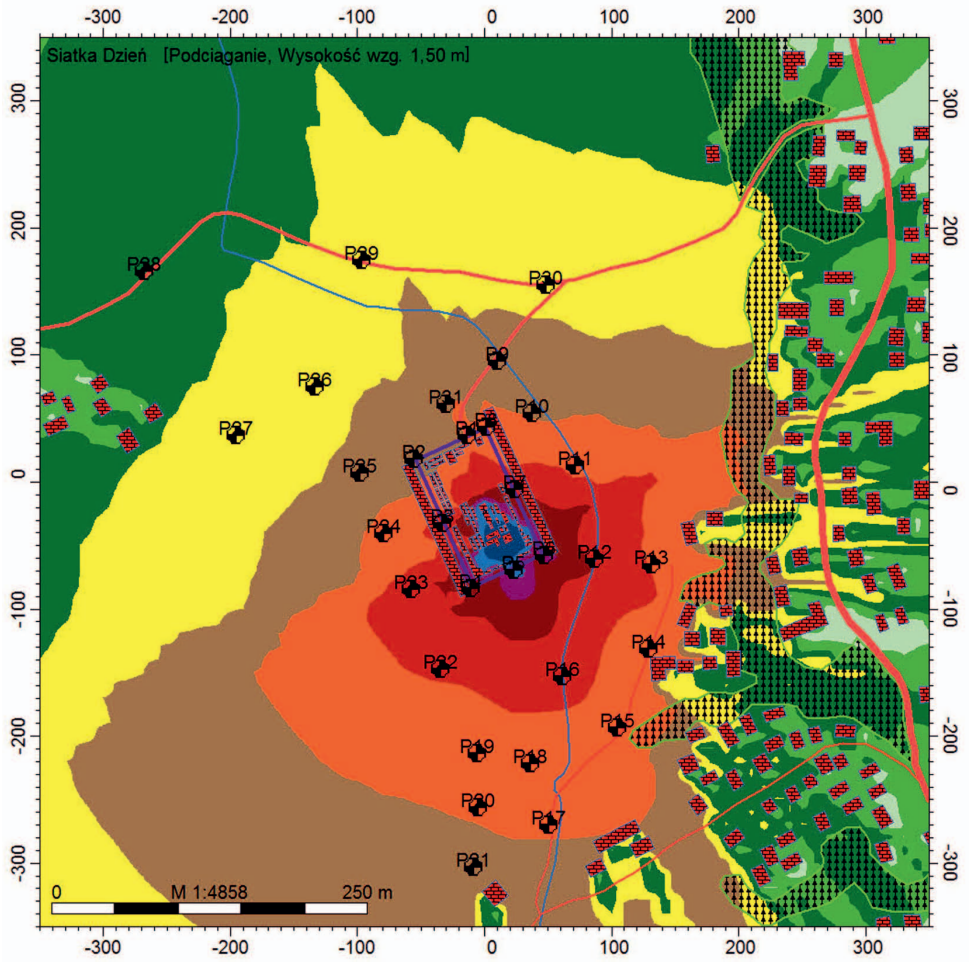

Rys. 6. Symulacja rozprzestrzeniania się hałasu wokół wiertni, odwiert Parkosz-2K - marsz kontrolny 
Tablica 7. Wartości poziomów mocy akustycznej poszczególnych emitorów otrzymane z symulacji; odwiert Parkosz-2K - etap rurowania

\begin{tabular}{|l|c|}
\hline \multicolumn{1}{|c|}{ Urządzenie } & $\begin{array}{c}\text { Określony w symulacji } \\
\text { poziom mocy akustycznej } \\
L_{W A}[\mathrm{~dB}]\end{array}$ \\
\hline $\begin{array}{l}\text { Agregat prądotwórczy } \\
\text { Caterpillar Cat C18 o mocy } \\
300 \mathrm{KM}\end{array}$ & 119,1 \\
\hline $\begin{array}{l}\text { Silnik Caterpillar Cat C15 } \\
\text { o mocy 500 KM, stanowiący } \\
\text { napęd wyciągu wiertniczego }\end{array}$ & 120,4 \\
\hline $\begin{array}{l}\text { Silnik jednostki napędowej } \\
\text { Top Drive }\end{array}$ & 105,7 \\
\hline Taśmy hamulcowe wyciągu & 101,2 \\
\hline $\begin{array}{l}\text { Silnik napędowy klucza hy- } \\
\text { draulicznego }\end{array}$ & 104,0 \\
\hline $\begin{array}{l}\text { Samojezdny dźwig do poda- } \\
\text { wania rur }\end{array}$ & 98,6 \\
\hline
\end{tabular}

Tablica 8. Wartości poziomów mocy akustycznej poszczególnych emitorów otrzymane z symulacji; odwiert Parkosz-2K - etap cementowania

\begin{tabular}{|l|c|}
\hline \multicolumn{1}{|c|}{ Urządzenie } & $\begin{array}{c}\text { Określony w symulacji } \\
\text { poziom mocy akustycznej } \\
L_{W A}[\mathrm{~dB}]\end{array}$ \\
\hline $\begin{array}{l}\text { Agregat prądotwórczy } \\
\text { Caterpillar Cat C18 o mocy } \\
300 \mathrm{KM}\end{array}$ & 109,9 \\
\hline $\begin{array}{l}\text { Silnik Caterpillar Cat D398 } \\
\text { o mocy 500 KM, stanowiący } \\
\text { zasilanie pompy płuczkowej }\end{array}$ & 112,2 \\
\hline $\begin{array}{l}\text { Samojezdny agregat cemen- } \\
\text { tacyjny }\end{array}$ & 113,5 \\
\hline Samojezdny mikser & 104,3 \\
\hline
\end{tabular}

W tablicy 9 dla przykładu przedstawiono porównanie wartości poziomu emisji hałasu uzyskanych z pomiarów w fazie wiercenia otworu ( $\mathrm{z}$ uwzględnieniem tła) z wartościami otrzymanymi na drodze symulacji przeprowadzonej w programie IMMI

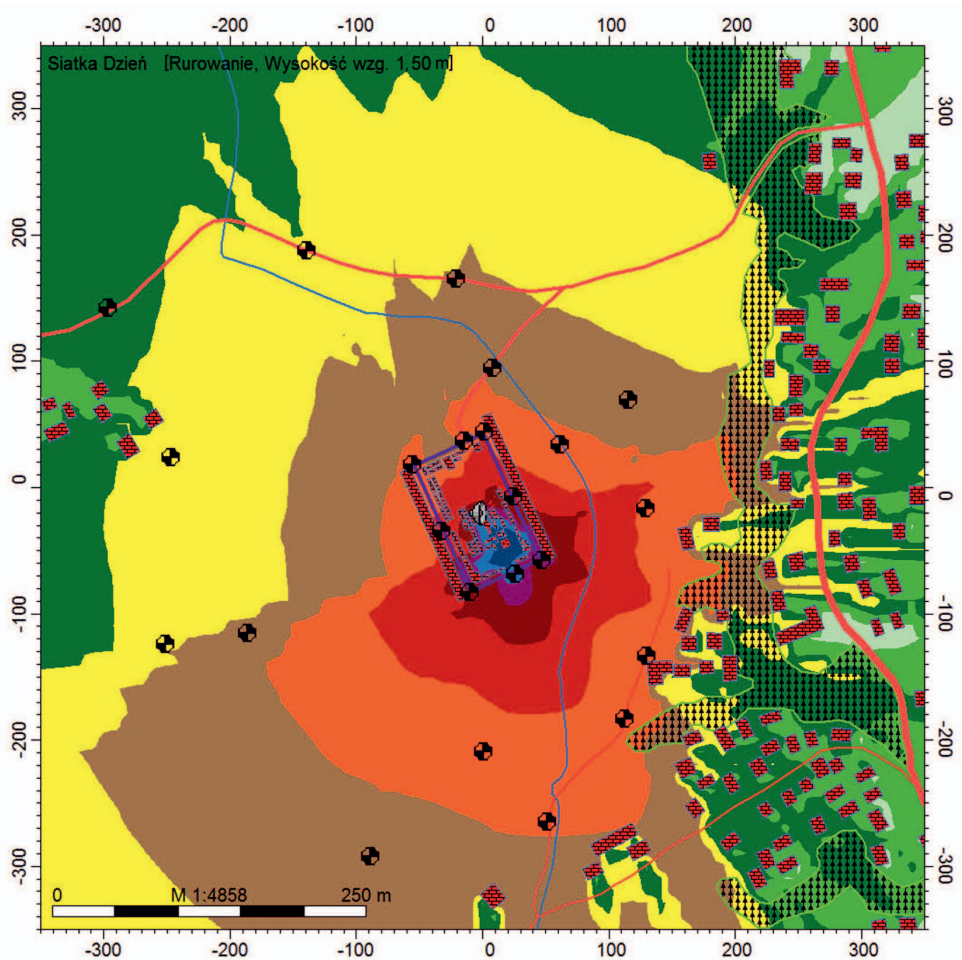

Rys. 7. Symulacja rozprzestrzeniania się hałasu wokół wiertni, odwiert Parkosz-2K - etap rurowania

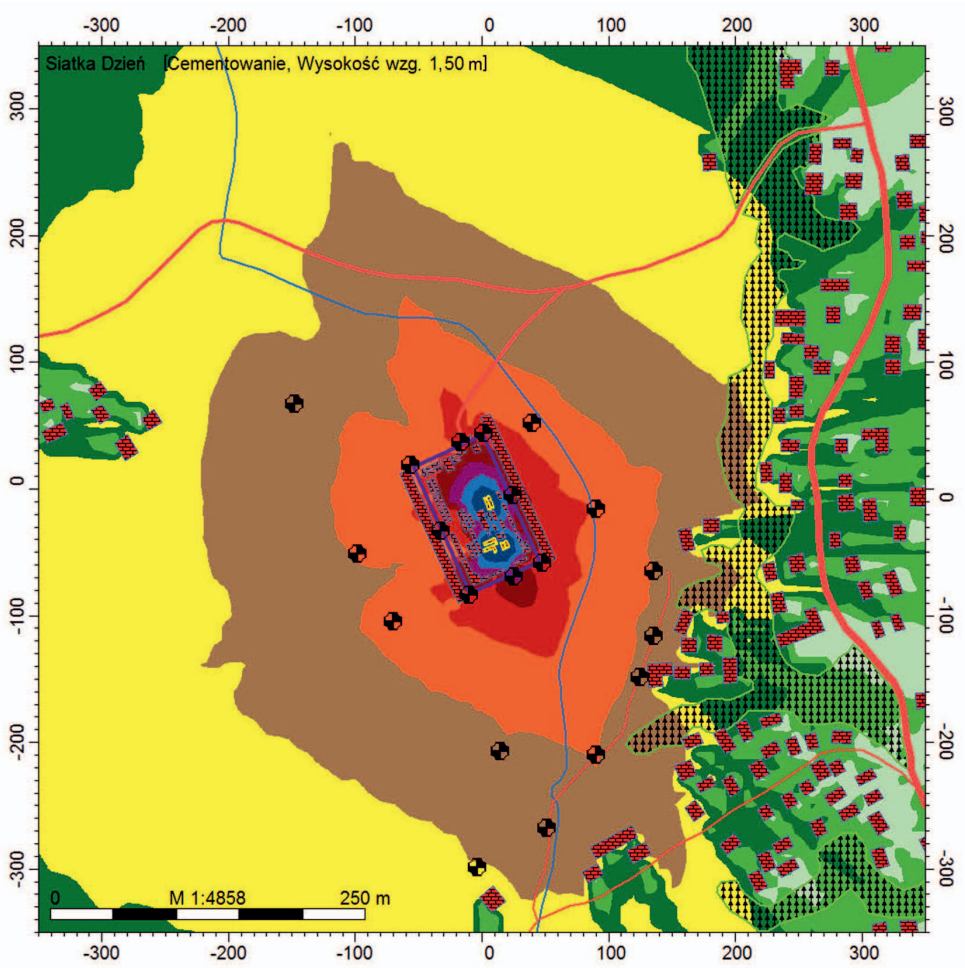

Rys. 8. Symulacja rozprzestrzeniania się hałasu wokół wiertni, odwiert Parkosz-2K - etap cementowania

w celu wyznaczenia przybliżonych poziomów mocy akustycznej źródeł hałasu, dla których sumaryczny poziom emisji z pracy wszystkich źródeł hałasu w punktach kontrolnych był jak najbliższy pomierzonym wartościom hałasu środowiskowego. 
Tablica 9. Porównanie poziomów emisji hałasu - zmierzonych i z symulacji; odwiert Parkosz-2K - etap wiercenia

\begin{tabular}{|c|c|c|c|}
\hline \multirow{2}{*}{$\begin{array}{l}\text { Oznaczenie punktu } \\
\text { pomiarowego }\end{array}$} & $\begin{array}{l}\text { Poziom emisji hałasu - } \\
\text { wartość zmierzona } L_{A e k}\end{array}$ & $\begin{array}{c}\text { Poziom emisji hałasu - } \\
\text { symulacja }\end{array}$ & Różnica \\
\hline & {$[\mathrm{dB}]$} & {$[\mathrm{dB}]$} & {$[\mathrm{dB}]$} \\
\hline $\mathrm{P} 1$ & 63,2 & 59,9 & $-3,3$ \\
\hline $\mathrm{P} 2$ & 55,3 & 57,5 & 2,2 \\
\hline P3 & 68,6 & 63,5 & $-5,1$ \\
\hline $\mathrm{P} 4$ & 65,8 & 70,6 & 4,8 \\
\hline P5 & 80,8 & 79,5 & $-1,3$ \\
\hline P6 & 73,4 & 73,8 & 0,4 \\
\hline P7 & 60,5 & 64,9 & 4,4 \\
\hline P8 & 55,4 & 59,8 & 4,4 \\
\hline P9 & 60,8 & 56,1 & $-4,7$ \\
\hline $\mathrm{P} 10$ & 60,3 & 58,2 & $-2,1$ \\
\hline P11 & 62,0 & 63,4 & 1,4 \\
\hline P12 & 60,7 & 59,3 & $-1,4$ \\
\hline P13 & 60,5 & 58,7 & $-1,8$ \\
\hline P14 & 63,9 & 58,7 & $-5,2$ \\
\hline $\mathrm{P} 15$ & 60,6 & 58,8 & $-1,8$ \\
\hline P16 & 60,3 & 56,8 & $-3,5$ \\
\hline $\mathrm{P} 17$ & 66,5 & 63,8 & $-2,7$ \\
\hline P18 & 59,7 & 58,4 & $-1,3$ \\
\hline P19 & 55,9 & 56,3 & 0,4 \\
\hline P20 & 52,6 & 54,7 & 2,1 \\
\hline P21 & 59,9 & 61,9 & 2,0 \\
\hline P22 & 58,0 & 53,8 & $-4,2$ \\
\hline $\mathrm{P} 23$ & 53,5 & 57,2 & 3,7 \\
\hline P24 & 48,7 & 49,8 & 1,1 \\
\hline $\mathrm{P} 25$ & 43,7 & 48,2 & 4,5 \\
\hline
\end{tabular}

\section{Podsumowanie}

Wykorzystanie programu IMMI do modelowania rozprzestrzeniania się hałasu w środowisku w połączeniu z wynikami pomiarów terenowych pozwoliło na przybliżone określenie poziomów mocy akustycznej urządzeń pracujących na różnych etapach wiercenia otworu. Uzyskane wartości poziomów mocy akustycznej mogą być pomocne przy prognozowaniu wpływu pracy tych urządzeń na klimat akustyczny dla celów opracowania ocen oddziaływania na środowisko pod kątem emisji hałasu z placu wiertni, gdy nieznane są parametry akustyczne urządzeń.
Trzeba jednak zauważyć, że prognozy sporządzane na podstawie symulacji rozprzestrzeniania się hałasu w środowisku są zawsze obarczone pewnym błędem i wartości poziomu hałasu uzyskane w drodze symulacji będą odbiegać od wartości rzeczywistych. Jest to spowodowane m.in. niemożliwością zdefiniowania i określenia na potrzeby modelowania charakterystyk akustycznych wszystkich instalacji i urządzeń emitujących hałas, których funkcjonowanie ma także wpływ na sumaryczną emisję hałasu z danego obiektu.

Prosimy cytować jako: Nafta-Gaz 2018, nr 4, s. 319-328, DOI: 10.18668/NG.2018.04.08

Artykuł nadesłano do Redakcji 7.12.2017 r. Zatwierdzono do druku 9.03.2018 r.

Artykuł powstał na podstawie pracy statutowej pt.: Badania hałasu wraz z ocena oddziaływania na klimat akustyczny urzadzeń i instalacji stosowanych w górnictwie nafty i gazu - praca INiG - PIB na zlecenie MNiSW; nr zlecenia: 0018/SN/17/01, nr archiwalny: DK-4100-5/17.

\section{Literatura}

[1] Uliasz-Misiak B., Dubiel S.: Aspekty środowiskowe w zarzadzaniu złożem węglowodorów w fazie jego zagospodarowywania. Przegląd Górniczy 2015, nr 4, s. 56-62.
[2] Urba R.: Niepewność pomiaru fizykochemicznych czynników środowiskowych $w$ zakładach górnictwa nafty i gazu. Nafta-Gaz 2010, nr 7, s. 573-576. 
[3] Urba R.: Zastosowanie narzędzi programistycznych do oceny hałasu wokół eksploatowanych wiertnic. Nafta-Gaz 2016, $\mathrm{nr} 2$, s. 118-123, DOI: 10.18668/NG.2016.02.07.

[4] Urba R., Kwilosz T.: Emisja hałasu urządzeń wiertniczych do środowiska obstugi wiertnic. Nafta-Gaz 2012, nr 12, s. 1055-1062.

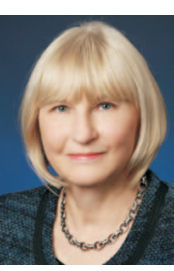

Mgr inż. Joanna ZALESKA-BARTOSZ

Starszy specjalista badawczo-techniczny w Zakładzie

Ocen Środowiskowych.

Instytut Nafty i Gazu - Państwowy Instytut Badawczy

ul. Lubicz 25 A

31-503 Kraków

E-mail: zaleska-bartosz@inig.pl

\section{Akty prawne i normatywne}

[5] Rozporządzenie Ministra Środowiska z dnia 14 czerwca 2007 r. w sprawie dopuszczalnych poziomów hałasu w środowisku (tj. Dz.U. z 2014 r., poz. 112)

[6] Rozporządzenie Ministra Środowiska z dnia 30 października 2014 r. w sprawie wymagań w zakresie prowadzenia pomiarów wielkości emisji oraz pomiarów ilości pobieranej wody (Dz.U. z 2014 r., poz. 1542).

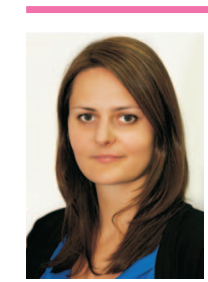

Mgr Joanna NIEMCZEWSKA

Asystent w Zakładzie Ocen Środowiskowych. Instytut Nafty i Gazu - Państwowy Instytut Badawczy ul. Lubicz 25 A

31-503 Kraków

E-mail: joanna.niemczewska@inig.pl

\section{OFERTA}

\section{ZAKŁAD OCEN ŚRODOWISKOWYCH}

Zakres działania:

- $\quad$ opracowywanie raportów o oddziaływaniu na środowisko przedsięwzięć branży górnictwa nafty i gazu, gazownictwa i gospodarki odpadami;

- opracowywanie raportów dotyczących emisji i rozprzestrzeniania się zanieczyszczeń gazowych i pyłowych do powietrza z instalacji przemysłowych;

- $\quad$ prognozy emisji i rozprzestrzeniania się hałasu z instalacji przemysłowych;

- $\quad$ prognozowanie produktywności gazowej składowisk odpadów komunalnych i ich weryfikacja poprzez testy aktywnego odgazowania;

- $\quad$ opracowywanie koncepcji technologicznych instalacji do odgazowania składowisk i utylizacji biogazu wraz z doradztwem technicznym i oceną ekonomiczną energetycznego wykorzystania gazu;

- $\quad$ prowadzenie monitoringu oraz nadzór nad instalacjami odgazowania składowisk odpadów;

- ocena zagrożeń powodowanych ekshalacjami metanu (złoża węglowodorów, składowiska odpadów).

Kierownik: mgr inż. Joanna Zaleska-Bartosz

Adres: ul. Bagrowa 1, 30-733 Kraków

Telefon: 126177478

Fax: 126531665

E-mail: zaleska-bartosz@inig.pl 


\title{
Badania ograniczenia pienienia cieczy wodorozcieńczalnych
}

\begin{abstract}
W pracy badano wodorozcieńczalny koncentrat półsyntetyczny oraz wodorozcieńczalny koncentrat wysokoolejowy cieczy chłodząco-smarujących z pięcioma środkami przeciwpiennymi o różnym charakterze chemicznym. W koncentratach zastosowano, zalecane przez producentów, minimalne i maksymalne stężenia środków przeciwpiennych. Z koncentratów sporządzono 5-procentową $(\mathrm{m} / \mathrm{m})$ emulsje w wodzie o twardościach: 0 , 15 i $30^{\circ} \mathrm{n}$. W badaniach porównawczych zastosowano procedurę INiG - PiB oznaczania skłonności do pienienia emulsji cieczy wodorozcieńczalnych. Dodatkowo zbadano ich napięcie powierzchniowe, a także $\mathrm{pH}$.
\end{abstract}

Słowa kluczowe: pienienie, środek przeciwpienny, wodorozcieńczalne ciecze do obróbki metali.

\section{Foam reduction tests for soluble metalworking fluids}

Concentrates of a semi-synthetic watermiscible coolant and a water soluble metalworking fluid with five different defoamers were investigated. Concentrates with water, recommended by manufacturers, minimum and maximum concentrations of defoamers were used. Concentrates of $5 \%(\mathrm{~m} / \mathrm{m})$ emulsions in water of hardness: 0,15 and $30^{\circ} \mathrm{n}$. In comparative studies, the author's INiG - PiB procedure was used to determine the foaming tendency of the watermiscible metalworking fluids. Additionally, the surface tension and $\mathrm{pH}$ were also investigated.

Key words: foaming, defoamer, antifoamer, soluble metalworking fluid.

\section{Wstęp}

Wodorozcieńczalne ciecze wykorzystywane w przemyśle to przede wszystkim ciecze chłodząco-smarujące do powierzchniowej obróbki metali. Wodorozcieńczalne ciecze chłodząco-smarujące (w postaci chłodziw emulsyjnych) stosuje się w procesach obróbki skrawaniem, tj. w obróbce wiórowej i ściernej: stali, żeliwa, metali nieżelaznych i ich stopów, gdzie wymagane jest szybkie odprowadzenie ciepła, właściwe smarowanie i dobre właściwości myjące. Gotową ciecz chłodząco-smarującą (emulsję) otrzymuje się poprzez wymieszanie koncentratu $\mathrm{z}$ wodą, najczęściej z wykorzystaniem dostępnego ujęcia wody. Zalecane stężenie koncentratu w wodzie zależy od rodzaju obróbki oraz od charakteru chemicznego stosowanej cieczy chłodząco-smarującej (emulsji) [18, 21]. Koncentrat to układ złożony z olejów (mineralnych, półsyntetycznych, syntetycznych), emulgatora oraz różnych dodatków (antyutleniaczy, inhibitorów korozji, dodatków przeciwzużyciowych EP, przeciwpiennych i biocydów), zależnie od przeznaczenia emulsji $[18,19]$. Dzięki stosowaniu w ich skła- dzie emulgatorów możliwe jest wytworzenie stabilnych emulsji chłodziw otrzymywanych z koncentratów, zawierających oleje oraz inne niemieszające się z wodą składniki. W zależności od proporcji składników wchodzących w skład koncentratów wodorozcieńczalnych cieczy chłodząco-smarujących, a szczególnie zawartego w nich oleju, stosowany jest często podział na ciecze [7, 16-19]:

- konwencjonalne (wysokoolejowe), w których głównym (pod względem udziału) składnikiem kompozycji jest olej mineralny $-\mathrm{z}$ wodą tworzą one mleczne ciecze makroemulsyjne,

- półsyntetyczne, w których udział środków powierzchniowo czynnych i dodatków jest dominujący, przewyższający udział olejów mineralnych - tworzą one $\mathrm{z}$ wodą ciecze półprzeźroczyste lub transparentne,

- syntetyczne, tworzące z wodą roztwory lub ciecze mikroemulsyjne, w których stosowane są glikole, poliglikole, lekkie oleje syntetyczne lub estrowe. 
Wykorzystywanie chłodziw zamiast olejów obróbczych w znacznym stopniu obniża koszty eksploatacyjne z uwagi na wysokie rozcieńczanie wodą, brak zaolejenia wiórów, możliwość utrzymania czystości hali produkcyjnej oraz zmniejszenie emisji mgły olejowej. Wiąże się ono jednak z koniecznością prowadzenia częstej kontroli i pielęgnacji emulsji w trakcie eksploatacji. Bardzo ważnym kryterium jest dobór środka do rodzaju obrabianego materiału. W zależności od składu i twardości wody wykorzystanej do sporządzenia emulsji ciecze chłodząco-smarujące wykazują różne skłonności do pienienia. Tworzenie piany jest zjawiskiem niekorzystnym, ponieważ zakłóca pracę urządzeń i może podczas eksploatacji maszyn powodować następujące skutki:

- redukcję efektywności emulsji, czyli niedostateczne smarowanie, w rezultacie zbyt małej ilości środka smarowego doprowadzanego do skojarzenia trącego,

- niedostateczne odprowadzanie ciepła, a tym samym problemy z zapewnieniem odpowiedniej jakości obrabianych detali,

- wypływanie cieczy eksploatacyjnych ze zbiorników maszyny, np. poprzez otwory odpowietrzające,

- zwiększenie skłonności do występowania zjawiska kawitacji (gwałtownej przemiany fazowej z fazy ciekłej w fazę gazową pod wpływem zmniejszenia ciśnienia), a tym samym redukcję wydajności pomp,

- redukcję pojemności pomp i zbiorników,

- wzrost intensywności namnażania bakterii,

- flotację zanieczyszczeń, tworzenie depozytów zanieczyszczeń,

- częste przestoje w produkcji spowodowane czyszczeniem zbiorników,

- problemy z drenażem sit i filtrów,

- zwiększenie kosztów produkcji związanych z częstszą wymianą eksploatowanej emulsji oraz eliminacją wybrakowanych produktów.

Aby uniknąć powyższych problemów, wodorozcieńczalne ciecze chłodząco-smarujące powinny charakteryzować się brakiem lub jak najmniejszą skłonnością do pienienia, co można uzyskać poprzez dobór odpowiedniego środka przeciwpiennego.

Pierwotnie jako środki przeciwpienne (np. w płynach hydraulicznych) stosowano oleje silikonowe ze względu na ich niewielkie napięcie powierzchniowe. Wadą tej metody było częściowe odparowywanie tych olejów. Obecnie problem ten został rozwiązany poprzez wykorzystanie organomodyfikowanych siloksanów.

Większość nowoczesnych i efektywnych środków przeciwpiennych jest wieloskładnikowa. Zawierają one w swoim składzie mieszaninę olejów silikonowych, surfaktantów silikonowych lub silikażeli z możliwie dwoma lub więcej typami rozproszonych hydrofobowych agregatów (wielkości około $1 \mu \mathrm{m}$, gęstości względnej 1,0 $\div 1,3$ i szorstkim kształcie fraktalnym).
Takie mieszaniny wykazują dużą skuteczność już przy niewielkim stężeniu $(10 \div 1000 \mathrm{ppm})$. Te wieloskładnikowe środki zbudowane są ze stałego ,aktywatora”, w postaci hydrofobizowanej krzemionki lub szkła, oraz ciekłego „nośnika”, w postaci węglowodoru, polidimetylosiloksanu (PDMS) lub oleju $[2-4,9,13-15,20]$.

Jednozadaniowe środki przeciwpienne stosuje się przeciwko pianom wodnym w wielu różnych formach: w postaci rozpuszczalnych lub nierozpuszczalnych cieczy, olejów, żeli, stałych hydrofobowych cząstek, emulsji i mikroemulsji. Są one mniej skuteczne, ale zdecydowanie tańsze. Wśród typowych związków chemicznych, jakie wchodzą w ich skład, można wymienić: fosforan tributylu (TBP), polidimetylosiloksan (PDMS), płyny silikonowe, aminy alkilowe, amidy, tioetery, oleje mineralne i roślinne, woski, estry kwasów tłuszczowych, alkohole (np. oktanol), kwasy tłuszczowe oraz ich pochodne (olej talowy, stearynian glinu oraz wapniowe, glinowe, cynkowe sole kwasów tłuszczowych), a także wiele różnych typów cząstek stałych [9-15]. Do środków tych można również zaliczyć estry glicerylu oraz syntetyczne estry alkoholi wielowodorotlenowych. Obecnie trwają również badania nad zastosowaniem w środkach przeciwpiennych cieczy jonowych, np. opartych na fosfonianach [1].

Do grupy związków przeciwpiennych należą także niejonowe etoksylowane i propoksylowane kopolimery blokowe typu PEO-PPO-PEO lub PPO-PEO-PPO i poloksamery, nazywane cloud point antifoamers: copolymers [9,13, 14]. Polarność tego typu kopolimerów zależy od stosunku komponentów hydrofilowych (politlenku etylenu, PEO) do hydrofobowych (politlenku propylenu, PPO). Cloud point antifoamers dość dobrze rozpuszczają się $\mathrm{w}$ wodzie $\mathrm{w}$ niskich temperaturach, natomiast tylko częściowo w wysokich temperaturach, a powyżej temperatury mętnienia (ang. cloud point) roztwór środka przeciwpiennego ulega zmianie fazowej, tworząc dwa sprzężone roztwory (dwie fazy): jeden bardziej rozcieńczony, a drugi stężony. W temperaturze mętnienia wydzielające się krople kopolimerów powodują, że roztwory (fazy) stają się mętne. Temperatura ta może być modyfikowana poprzez zmianę stosunku PEO/PPO. Przeważnie tego typu związki są dodawane do pieniących roztworów surfaktantów na bazie wody w celu uzyskania efektu przeciwpiennego w temperaturze zbliżonej do temperatury mętnienia. Natomiast w niektórych przypadkach, ze względu na mieszalność z innymi surfaktantami, temperatura mętnienia może wzrosnąć lub nawet zostać całkowicie wyeliminowana.

Jako że istnieje bardzo wiele różnych związków chemicznych charakteryzujących się właściwościami przeciwpiennymi, jest wiele alternatywnych mechanizmów wyjaśniających sposób ich działania [3, 5, 6, 14]. Niemniej jednak główną funkcją środków zapobiegających pienieniu jest zastąpienie lub zredukowanie ilości generującego pianę środka 
powierzchniowo czynnego obecnego na powierzchni zetknięcia się dwóch faz, co ostatecznie prowadzi do mniejszej stabilności filmu piany. Substancja chemiczna zapobiegająca pienieniu musi być przy tym nierozpuszczalna w ośrodku powodującym pienienie i równocześnie odporna na rozkład chemiczny $[8,9,14]$. Zasadnicze wymaganie, jakie muszą spełniać środki przeciwpienne, polega na ich zdolności przedostawa- nia się na granicę faz powietrze-ciecz, dlatego też muszą posiadać odpowiednio niskie napięcie powierzchniowe (mniejsze niż napięcie powierzchniowe cieczy, do której są dodawane) [14]. W przypadku pian wodnych stosunkowo łatwo jest sprostać temu wymaganiu, natomiast dla pian niewodnych można osiągnąć taki efekt tylko poprzez zastosowanie specyficznych surfaktantów (opartych na olejach silikonowych).

\section{Próbki}

Do badań wytypowano dwa koncentraty bazowych cieczy chłodząco-smarujących:

- koncentrat 1 - cieczy półsyntetycznej,

- koncentrat 2 - cieczy wysokoolejowej.

Oba koncentraty powstały z wykorzystaniem komercyjnych składników. $Z$ tak otrzymanych bazowych koncentra- tów przygotowano próbki koncentratów, dodając do nich środki przeciwpienne o różnym charakterze chemicznym, w minimalnych i maksymalnych zalecanych przez producentów stężeniach. Szczegółową charakterystykę tych środków przeciwpiennych, a także zalecane minimalne i maksymalne stężenie przedstawiono w tablicy 1. Dane te uzyskano

Tablica 1. Charakterystyka dodatków przeciwpiennych

\begin{tabular}{|c|c|c|}
\hline \multirow{5}{*}{ Dodatek P1 } & Charakter chemiczny & mieszanina trójwymiarowego siloksanu z polioksyalkilanem \\
\hline & Rekomendowane dozowanie $[\%(\mathrm{~m} / \mathrm{m})]$ & $0,05 \div 0,1$ \\
\hline & Wygląd w temperaturze $20^{\circ} \mathrm{C}$ & nieprzeźroczysta ciecz barwy białej do jasnożółtej \\
\hline & Lepkość dynamiczna w temperaturze $20^{\circ} \mathrm{C}[\mathrm{mPa} \cdot \mathrm{s}]$ & 1350 \\
\hline & Gęstość w temperaturze $20^{\circ} \mathrm{C}[\mathrm{g} / \mathrm{ml}]$ & 0,838 \\
\hline \multirow{5}{*}{ Dodatek P2 } & Charakter chemiczny & mieszanina trójwymiarowego siloksanu z wodą \\
\hline & Rekomendowane dozowanie $[\%(\mathrm{~m} / \mathrm{m})]$ & $0,1 \div 0,5$ \\
\hline & Wygląd w temperaturze $20^{\circ} \mathrm{C}$ & nieprzeźroczysta ciecz barwy białej \\
\hline & Lepkość dynamiczna w temperaturze $20^{\circ} \mathrm{C}[\mathrm{mPa} \cdot \mathrm{s}]$ & 1250 \\
\hline & Gęstość w temperaturze $20^{\circ} \mathrm{C}[\mathrm{g} / \mathrm{ml}]$ & 0,827 \\
\hline \multirow{6}{*}{ Dodatek P3 } & Charakter chemiczny & $\begin{array}{c}\text { mieszanina kopolimeru blokowego ( } \mathrm{z} \text { dwiema grupami glikolu } \\
\text { polietylenowego przyłączonymi do centralnej grupy glikolu } \\
\text { propylenowego) z wodą }\end{array}$ \\
\hline & Rekomendowane dozowanie $[\%(\mathrm{~m} / \mathrm{m})]$ & $0,1 \div 0,5$ \\
\hline & Wygląd w temperaturze $20^{\circ} \mathrm{C}$ & bezbarwna ciecz \\
\hline & Lepkość dynamiczna w temperaturze $20^{\circ} \mathrm{C}[\mathrm{mPa} \cdot \mathrm{s}]$ & 350 \\
\hline & Gęstość w temperaturze $20^{\circ} \mathrm{C}[\mathrm{g} / \mathrm{ml}]$ & 1,02 \\
\hline & Temperatura mętnienia $\left(1 \% \mathrm{w} \mathrm{H}_{2} \mathrm{O}_{\text {destyl. }}\right)\left[{ }^{\circ} \mathrm{C}\right]$ & 23 \\
\hline \multirow{5}{*}{ Dodatek P4 } & Charakter chemiczny & mieszanina polidimetylosiloksanu z wodą \\
\hline & Rekomendowane dozowanie $[\%(\mathrm{~m} / \mathrm{m})]$ & $0,1 \div 0,5$ \\
\hline & Wygląd w temperaturze $20^{\circ} \mathrm{C}$ & nieprzeźroczysta ciecz barwy białej \\
\hline & Lepkość dynamiczna w temperaturze $20^{\circ} \mathrm{C}[\mathrm{mPa} \cdot \mathrm{s}]$ & 660 \\
\hline & Gęstość w temperaturze $20^{\circ} \mathrm{C}[\mathrm{g} / \mathrm{ml}]$ & 1,10 \\
\hline \multirow{6}{*}{ Dodatek P5 } & Charakter chemiczny & $\begin{array}{l}\text { mieszanina polidimetylosiloksanów, cyklosiloksanów } \\
\text { i krzemionki z wodą }\end{array}$ \\
\hline & Zawartość części stałych [\%] & $10 \div 14$ \\
\hline & Rekomendowane dozowanie $[\%(\mathrm{~m} / \mathrm{m})]$ & $0,05 \div 0,1$ \\
\hline & Wygląd w temperaturze $20^{\circ} \mathrm{C}$ & nieprzeźroczysta ciecz barwy białej \\
\hline & Lepkość dynamiczna w temperaturze $20^{\circ} \mathrm{C}[\mathrm{mPa} \cdot \mathrm{s}]$ & 500 \\
\hline & Gęstość w temperaturze $20^{\circ} \mathrm{C}[\mathrm{g} / \mathrm{ml}]$ & 0,98 \\
\hline
\end{tabular}


od producentów tych dodatków na podstawie świadectw jakości, informacji technicznych (TDS) oraz kart charakterystyki (MSDS).

Następnie przygotowano próbki cieczy chłodząco-smarujących, emulsje typu W/O (woda w oleju). Te emulsje, o stę- żeniu 5\% $(\mathrm{m} / \mathrm{m})$, sporządzono na wodach o trzech różnych twardościach: 0,15 i $30^{\circ} \mathrm{n}$. Wodę destylowaną $\left(0^{\circ} \mathrm{n}\right)$ gotowano przez około 30 minut w celu usunięcia kwasu węglowego, natomiast wodę o twardościach $15^{\circ} \mathrm{n}$ i $30^{\circ} \mathrm{n}$ przygotowano zgodnie z normą PN-M-55789 [24].

\section{Metodyka badań}

W kolejnym etapie prac emulsje te, czyli gotowe do użycia ciecze chłodząco-smarujące, poddano badaniom, oznaczając:

- skłonność do pienienia - metodą INiG - PIB,

- napięcie powierzchniowe - według PN-C-04809 [22],

- $\mathrm{pH}$ - według PN-C-04963 [23].

Wyniki tych badań przedstawiono w tablicach 2-5.

\section{Skłonność do pienienia emulsji cieczy wodorozcieńczalnych - metoda INiG - PIB}

Skłonność do pienienia cieczy określa się za pomocą dwóch parametrów: ilości piany powstałej podczas napowietrzania oraz szybkości gaśnięcia piany.

Zasada metody polega na przedmuchiwaniu powietrza przez badaną próbkę płynu ze stałą prędkością, w określonej temperaturze i określonym czasie, a następnie na pomiarze objętości powstałej piany i pomiarze czasu jej zaniku. Objętość piany obliczono z różnicy zanotowanych poziomów piany i płynu, a za moment zaniku piany przyjęto chwilę pojawienia się na powierzchni emulsji pierwszego „oka”, czyli wolnego od piany lustra emulsji. Warunki badania:

- temperatura: $20 \pm 0,1^{\circ} \mathrm{C}$,

- objętość próbki: $145 \mathrm{ml}$,

- przepływ powietrza: $1000 \pm 25 \mathrm{ml} / \mathrm{min}$,

- czas przepływu powietrza: $5 \mathrm{~min}$.

Do badań wykorzystano stanowisko (fotografia 1) składające się z:

- cylindra pomiarowego o pojemności $600 \mathrm{ml} \mathrm{z}$ podziałką umożliwiającą odczyt z dokładnością do $5 \mathrm{ml}$,

- łaźni wodnej o pojemności około $5000 \mathrm{ml} \mathrm{z}$ termoregulatorem umożliwiającym utrzymanie temperatury z dokładnością do $1^{\circ} \mathrm{C}$,

- bełkotki napowietrzającej z porowatym kulistym spiekiem korundowym o średnicy 25,5 mm, maksymalnej średnicy porów $45 \mu \mathrm{m}$ i przepuszczalności powietrza przy ciśnieniu $250 \mathrm{mmH}_{2} \mathrm{O}$ wynoszącej $6400 \mathrm{ml} / \mathrm{min}$,

- termometru laboratoryjnego o zakresie pomiarowym $0 \div 40{ }^{\circ} \mathrm{C}$ umożliwiającego odczyt temperatury z dokładnością do $0,1^{\circ} \mathrm{C}$,

- rotametru pozwalającego na pomiar strumienia przepływającego powietrza z dokładnością do $25 \mathrm{ml} / \mathrm{min}$,

- źródła zasilania czystym i suchym powietrzem,

- płuczki szklanej wypełnionej watą, umieszczonej między źródłem zasilania powietrzem a rotametrem,
- sekundomierza umożliwiającego mierzenie czasu z dokładnością do $0,1 \mathrm{~s}$.

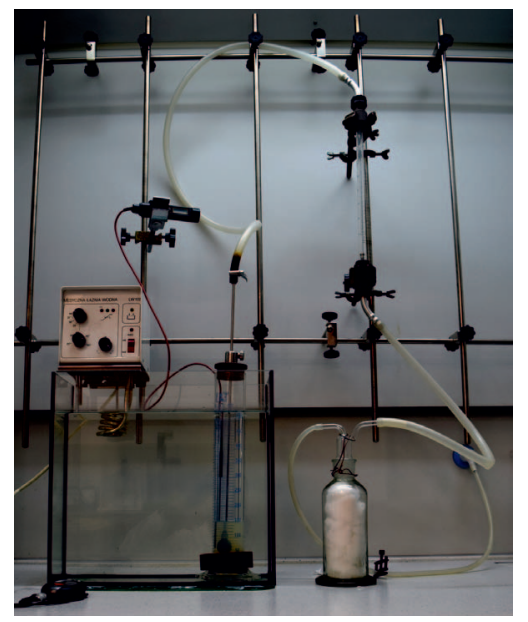

Fot. 1. Stanowisko badawcze do oznaczania skłonności do pienienia

(fot. INiG - PIB)

\section{Oznaczenie napięcia powierzchniowego}

Metoda oznaczania napięcia powierzchniowego na granicy faz ciecz-gaz polega na pomiarze siły, którą trzeba przyłożyć pionowo do pierścienia platynowego w celu oderwania go od tej powierzchni. Napięcie powierzchniowe przygotowanych próbek emulsji wobec powietrza zmierzono za pomocą tensjometru K8 firmy Petrotest (fotografia 2). Napięcie powierzchniowe wody destylowanej $\left(0^{\circ} \mathrm{n}\right)$ wyniosło $72,6 \mathrm{mN} / \mathrm{m}$, co pozwoliło uzyskać na tensjometrze wartość współczynnika korekcyjnego $k$ równą 1 .

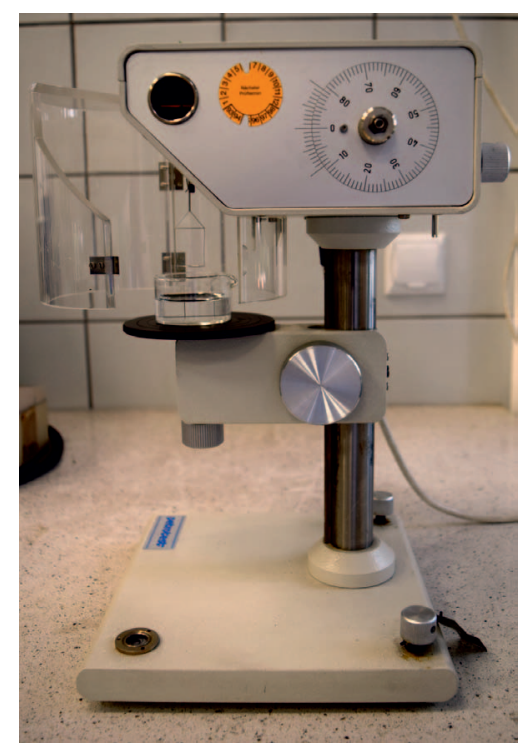

Fot. 2. Tensjometr K8

(fot. INiG - PIB) 


\section{Wyniki badań}

W tablicy 2 przedstawiono wyniki oznaczeń skłonności do pienienia, napięcia powierzchniowego oraz pH dla 5-proc. $(\mathrm{m} / \mathrm{m})$ emulsji sporządzonych z koncentratu 1 oraz dla koncentratu 1 wzbogaconego o dodatki przeciwpienne w minimalnych i maksymalnych stężeniach stosowania. Analogiczne wyniki dla koncentratu 2 przedstawiono w tablicy 3.

Wszystkie emulsje obu koncentratów sporządzone w wodzie o twardości $0^{\circ} \mathrm{n}$ wykazywały dużą skłonność do pienienia. Dla żadnej z nich nie udało się uzyskać wyników, ponieważ objętość powstającej piany przekraczała objętość cylindra pomiarowego - przyjęto, że w tych przypadkach ilość powstającej piany była większa niż $455 \mathrm{ml}$, ponieważ jest to maksymalna objętość piany, jaką można było zaobserwować w cylindrze o pojemności $600 \mathrm{ml}$.

Zaobserwowano znaczny wpływ twardości wody na skłonność do pienienia emulsji sporządzonych z obu koncentratów. Ze wzrostem twardości wody malała ilość powstającej piany oraz ulegał skróceniu czas zaniku piany. Ponadto dla każdej z próbek emulsji wraz ze wzrostem twardości wody malało napięcie powierzchniowe, a wzrastało $\mathrm{pH}$ emulsji.

W przypadku wszystkich emulsji sporządzonych z koncentratu 1 wzbogaconego o dodatki przeciwpienne, bez względu na twardość zastosowanej wody i rodzaj dodatku przeciwpiennego, wartości napięcia powierzchniowego i $\mathrm{pH}$ były niższe od analogicznych parametrów dla emulsji sporządzonych z koncentratu 1 bez dodatków przeciwpiennych. Ponadto wzrost stężenia wszystkich dodatków przeciwpiennych powodował obniżenie napięcia powierzchniowego i $\mathrm{pH}$ emulsji. Analogicznie rezultaty uzyskano w przypadku koncentratu 2 .

Dla obu koncentratów najskuteczniejszym spośród przebadanych dodatków przeciwpiennych okazał się dodatek P1 (na bazie trójwymiarowego siloksanu, w którym jako nośnik zastosowano polioksyalkilan) użyty w maksymalnym stężeniu $0,1 \%(\mathrm{~m} / \mathrm{m})$; zaobserwowano największe ograniczenie skłonności do pienienia wytworzonych emulsji - najmniej piany powstało, najszybciej zanikła.

Wszystkie emulsje (bez względu na twardość wody) sporządzone z obu koncentratów z dodatkiem P2 (na bazie trójwymiarowego siloksanu,

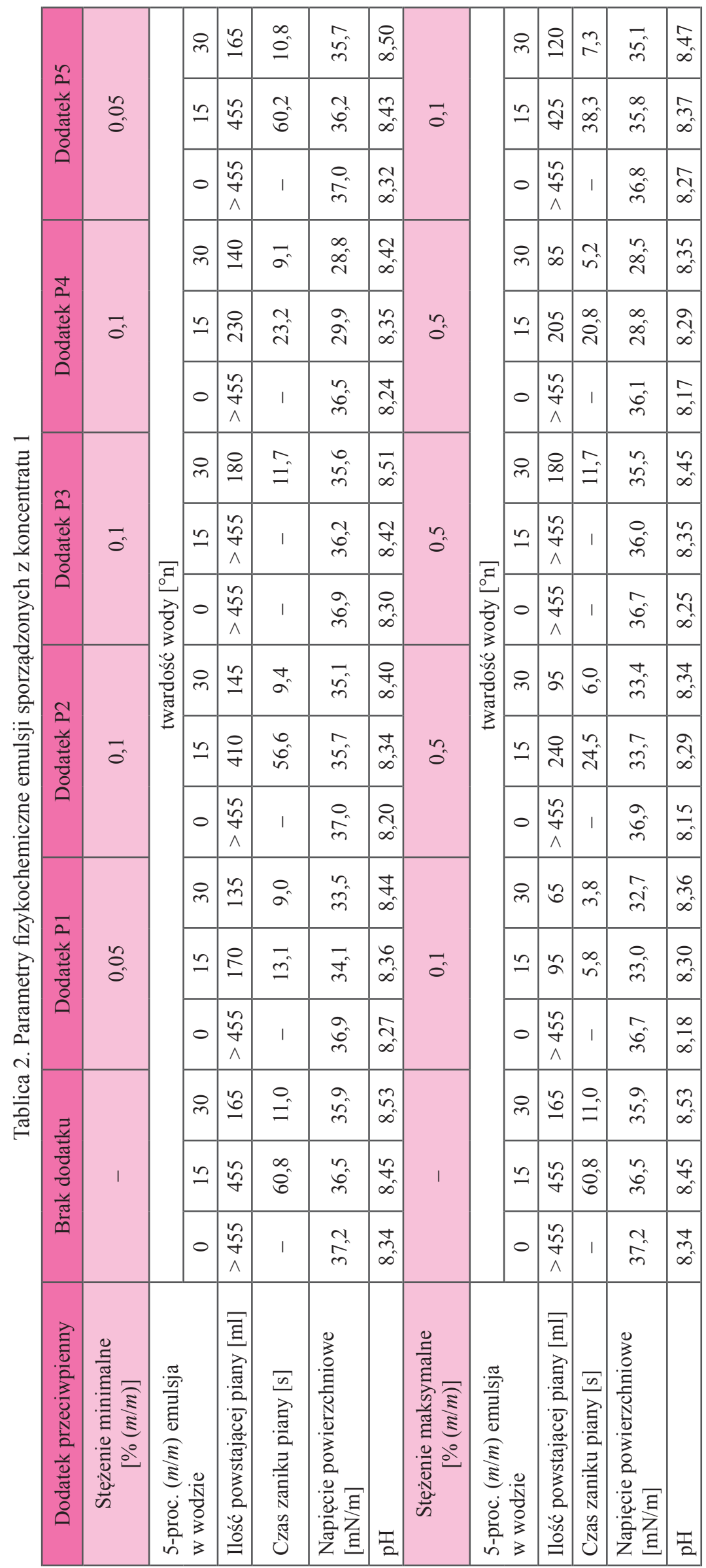

Nafta-Gaz, nr 4/2018 


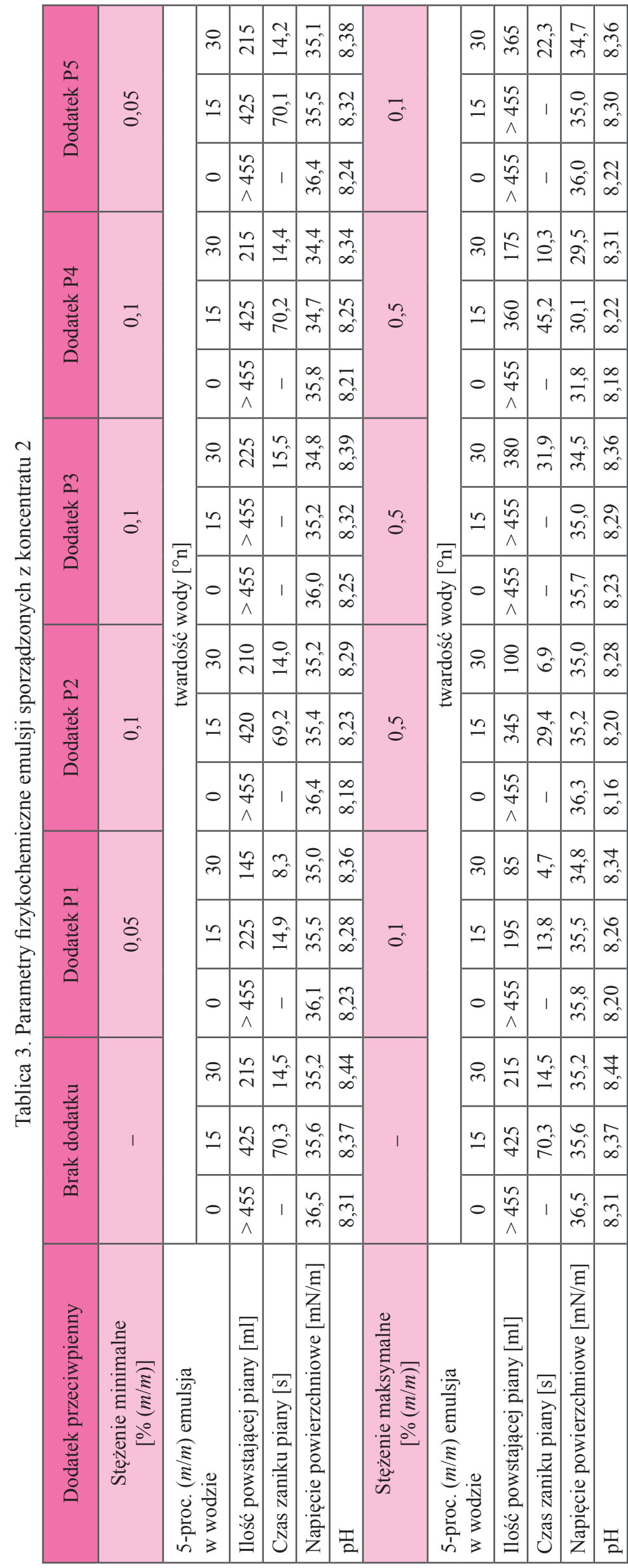

z wodą jako nośnikiem) wykazały najniższe wartości $\mathrm{pH}$ emulsji.

Dodatek P3 (z grupy dodatków przeciwpiennych clo$u d$ point antifoamers: block copolymers) nie sprawdził się jako środek ograniczający pienienie. Dla obu koncentratów pogarszał on skłonność emulsji do pienienia.

W przypadku obu koncentratów z dodatkiem $\mathrm{P} 4$ (na bazie polidimetylosiloksanu, z wodą jako nośnikiem) wszystkie sporządzone emulsje (bez względu na twardość wody) charakteryzowały się najniższymi wartościami napięcia powierzchniowego.

Zastosowanie w koncentracie 1 dodatku P5 dopiero w jego maksymalnym stężeniu pozwoliło na ograniczenie skłonności emulsji do pienienia. Natomiast użycie tego samego dodatku w jego maksymalnym stężeniu w koncentracie 2 zwiększyło skłonność do pienienia emulsji. Dodatek P5 jest dodatkiem na bazie polidimetylosiloksanu i cyklosiloksanów, w którym jako aktywator zastosowano krzemionkę, natomiast jako nośnik - wodę.

Dla 5-proc. $(\mathrm{m} / \mathrm{m})$ emulsji zarówno sporządzonych z koncentratu 1, jak i z koncentratu 2 zawierających badane dodatki przeciwpienne nie zaobserwowano zależności pomiędzy ograniczeniem skłonności pienienia emulsji przez te dodatki ( $\mathrm{tj}$. ilości powstającej piany i czasem jej zaniku) a napięciem powierzchniowym i pH.

\section{Podsumowanie}

Zastosowana w badaniach procedura oznaczania skłonności do pienienia emulsji cieczy wodorozcieńczalnych pozwoliła na porównywanie tej właściwości dla różnych cieczy wodorozcieńczalnych, a także użytych w ich koncentratach dodatków przeciwpiennych o różnych charakterach chemicznych.

W przypadku emulsji sporządzonych z obu koncentratów zaobserwowano znaczny wpływ twardości wody na ich skłonność do pienienia. Ze wzrostem twardości wody malała ilość powstającej piany oraz ulegał skróceniu czas jej zaniku. Ponadto dla każdej z próbek emulsji wraz ze wzrostem twardości wody malało napięcie powierzchniowe, a wzrastało $\mathrm{pH}$ emulsji.

Dla obu koncentratów najskuteczniejszym spośród przebadanych dodatków przeciwpiennych okazał się dodatek P1 (na bazie trójwymiarowego siloksanu, z polioksyalkilanem jako nośnikiem) zastosowany w maksymalnym zalecanym stężeniu $0,1 \%(\mathrm{~m} / \mathrm{m})$. Natomiast dodatek P3 (z grupy dodatków przeciwpiennych cloud point antifoamers: block copolymers) nie sprawdził się jako środek ograniczający pienienie. Charakter 
chemiczny dodatków przeciwpiennych oraz rodzaj struktury chemicznej związków silikonowych będących podstawowym składnikiem dodatków przeciwpiennych P1, P2, P4 i P5 miał istotny wpływ na skuteczność zmniejszania skłonności do pienienia badanych koncentratów cieczy wodorozcieńczalnych.

Prosimy cytować jako: Nafta-Gaz 2018, nr 4, s. 329-335, DOI: 10.18668/NG.2018.04.09

Artykuł nadesłano do Redakcji 24.11.2017 r. Zatwierdzono do druku 6.03.2018 r.

Artykuł powstał na podstawie pracy statutowej pt.: Badania ograniczenia pienienia cieczy wodorozcieńczalnych - praca INiG - PIB na zlecenie MNiSW; nr zlecenia: 0096/TO/17/01, nr archiwalny: DK-4100-83/17.

\section{Literatura}

[1] Bagwe R.: Phosponium Ionic Liquid as Defoamers: Structure - Property - Application Performance Correlation. $13^{\text {th }}$ IACIS International Conference on Surface and Colloid Science and the $83^{\text {rd }}$ ACS Colloid \& Surface Science Symposium, New York 14-19.06.2009.

[2] Denkov N.: Mechanism of Foam Destruction by Oil Based Antifoams. Langmuir 2004, vol. 20, nr 22, s. 9463-9505.

[3] Denkov N., Cooper P., Martin J.: Mechanism of Action of Mixed Solid-Liquid Antifoams. 1. Dynamics of Foam Film Rupture. Langmuir 1999, vol. 15, nr 24, s. 8514-8529.

[4] Denkov N.D., Marinova K.: Antifoam effects of solid particles, oil drops and oil-solid compounds in aqueous foams. Colloidal Particles at Liquid Interfaces, vol. 10, Cambridge University Press 2006, s. 383-444.

[5] Denkov N.D., Marinova K., Tcholakova S.: Mechanistic understanding of the modes of action of foam control agents. Advances in Colloid and Interface Science 2014, vol. 206, s. 57-67.

[6] Derjaguin B., Landau L.: Theory of the stability of strongly charged lyophobic sols and of the adhesion of strongly charged particles in solutions of electrolytes. Acta Physico Chemica U.R.S.S. 1941, vol. 14, s. 633-662.

[7] Dwuletzki H.: Schwerent Flammbare Hydraulikmedien von Typ HFA. II Międzynarodowa Konferencja: Teoretyczne i praktyczne aspekty stosowania środków smarowych, Ustroń 29-31.05.2006.

[8] Garrett P.R.: Defoaming: Antifoams and Mechanical Methods. Current Opinion in Colloid \& Interface Science 2015, vol. 20, nr 2, s. 81-91.

[9] Hilberer A., Chao S.-H.: Antifoaming agents. Encyclopedia of Polymer Science and Technology, Wiley and Sons Press 2012.

[10] Hill H., Eastoe J.: Foams: From nature to industry. Advances in Colloid and Interface Science 2017, vol. 247, s. 496-513.

[11] Karakashev S.I., Grozdanova M.V.: Foams and antifoams. Advances in Colloid and Interface Science 2012, vol. 176-177, s. $1-17$.

[12] Marinova K.G., Dimitrova L.M., Marinov R.Y., Denkov N.D., Kingma A.: Impact of the surfactant structure on the foaming/ defoaming performance of nonionic block copolymers in $\mathrm{Na}$ caseinate solutions. Bulgarian Journal of Physics 2012, vol. 39, nr 1, s. 53-64.

[13] Owen M.J.: Defoamers. [W:] Kirk-Othmer (ed.), Encyclopedia of Chemical Technology. Wiley and Sons Press, New Jersey 2000.

[14] Pugh R.J.: Bubble and Foam Chemistry. Cambridge University Press 2016, s. 1-48.

[15] Pugh R.J.: Foam Breaking in Aqueous Systems. [W:] Holmberg E.K. (ed.): Handbook of Applied Surface and Colloid Chemistry. Wiley and Sons Press, New Jersey 2001.

[16] Rembiesa-Śmiszek A.: Trudnopalne ciecze hydrauliczne HFC i HFC-E zawierajace polialkilenoglikole. Nafta-Gaz 2013, nr 3, s. 235-240.

[17] Rutkowska M., Skibińska A.: Opracowanie nowej generacji płynów do obróbki metali oraz kompleksowej technologii ich wytwarzania opartej na bazach olejowych, pochodzacych z recyklingu olejów odpadowych. Sprawozdanie z projektu INNOTECH-K1/N1/62/149772/NCBR/12, Kraków, wrzesień 2012.

[18] Steinmec F.: Krajowe wodorozcieńczalne środki chłodzacosmarujace do obróbki metali skrawaniem. Nafta 1990, vol. 46, nr 1-3, s. 37-41.

[19] Steinmec F., Bednarska A., Łapa M.: Rozwój krajowych mikroemulsyjnych cieczy hydraulicznych HFAE. Nafta-Gaz 2009, nr 1, s. 37-43.

[20] Stocco A., Rio E., Binks B.P., Langevin D.: Aqueous foams stabilized solely by particles. Soft Matter 2011, vol. 7, no. 4, s. 1260.

[21] Strona internetowa: http://naftochem.pl/srodki-do-obrobki-skrawaniem/ (dostęp: 28.07.2017).

\section{Normy prawne i normatywne}

[22] PN-C-04809:1990 Środki powierzchniowo czynne. Oznaczanie napięcia powierzchniowego i napięcia międzyfazowego.

[23] PN-C-04963:1989 Analiza chemiczna-Oznaczanie pH wodnych roztworów produktów chemicznych.

[24] PN-M-55789:1992 Badania działania korodujacego cieczy technologicznych na stopy żelaza.



Mgr inż. Agnieszka SKIBIŃSKA

Asystent w Zakładzie Olejów, Środków Smarowych i Asfaltów.

Instytut Nafty i Gazu - Państwowy Instytut Badawczy ul. Lubicz $25 \mathrm{~A}$

31-503 Kraków

E-mail:agnieszka.skibinska@inig.pl 